United States

Department of

Agriculture

Forest Service

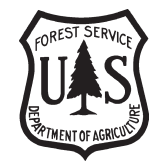

\section{Southern}

Research Station

General Technical

Report SRS-72

\section{Production of Short-Rotation Woody Crops Grown with a Range of Nutrient and Water Availability: Establishment Report and First-Year Responses}

M.D. Coleman, D.R. Coyle, J. Blake, K. Britton, M. Buford, R.G. Campbell, J. Cox, B. Cregg, D. Daniels, M. Jacobson, K. Johnsen, T. McDonald, K. McLeod, E. Nelson, D. Robison, R. Rummer, F. Sanchez, J. Stanturf, B. Stokes, C. Trettin, J. Tuskan, L. Wright, and S. Wullschleger

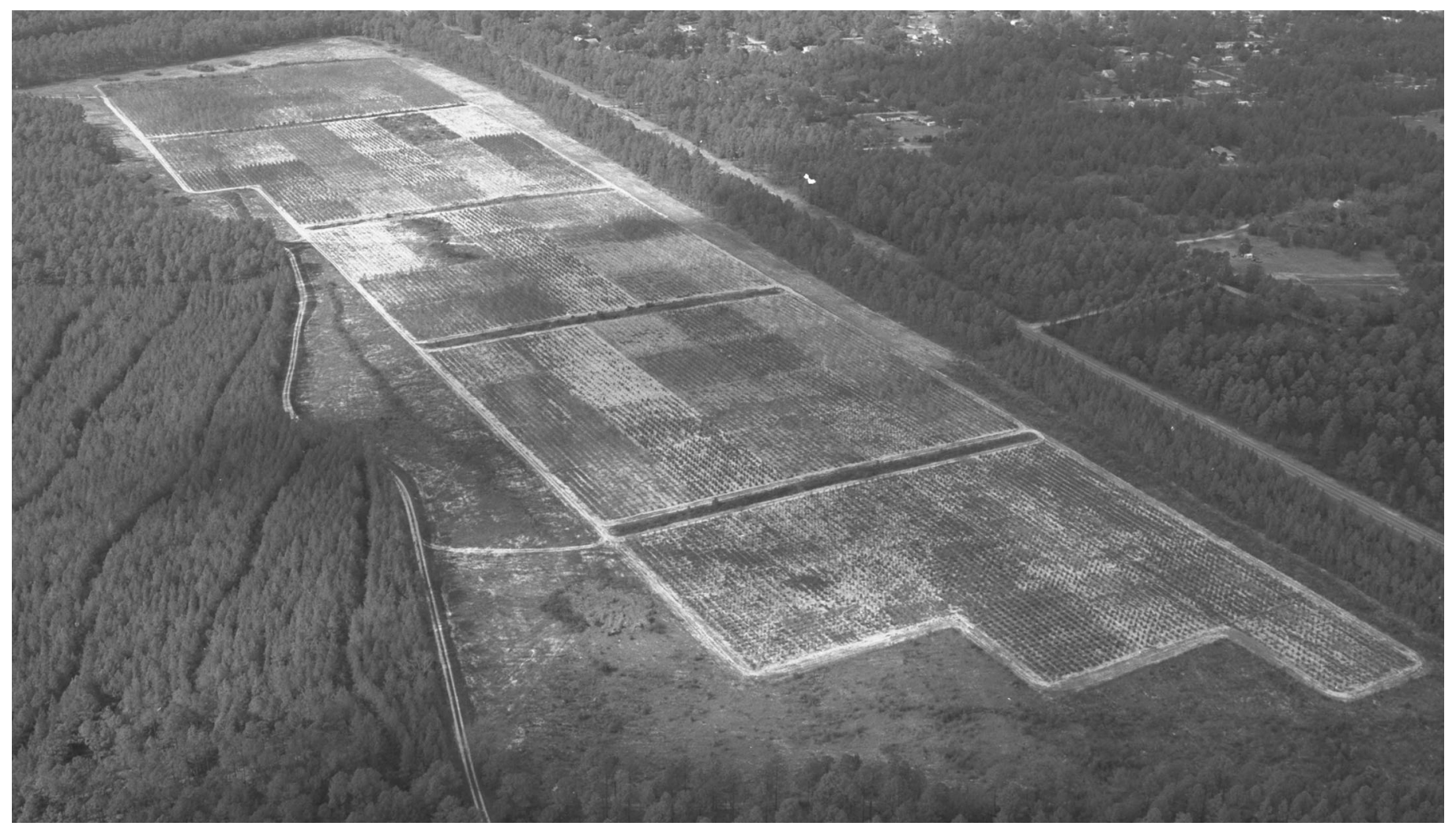




\section{The Authors:}

M.D. Coleman and D.R. Coyle, Biological Scientist and Biological Science Technician, USDA Forest Service, Southern Research Station, New Ellenton, SC; J. Blake, Assistant Manager, Research, USDA Forest Service, Savannah River, New Ellenton, SC; K. Britton, Project Leader, USDA Forest Service, Southern Research Station, Athens, GA; M. Buford, National Program Leader for Quantitative Analysis, USDA Forest Service, Vegetation Management and Protection Research, Washington, DC; R.G. Campbell, Team Leader, Southern Productivity Research, Weyerhaeuser Corporation, New Bern, NC; J. Cox, College Forest Manager, Department of Forestry, North Carolina State University, Raleigh, NC; B. Cregg, Assistant Professor, Department of Horticulture and Department of Forestry, Michigan State University, East Lansing, MI; D. Daniels, Professor of Forestry, D.B. Warnell School of Forest Resources, University of Georgia, Athens, GA; M. Jacobson, Manager, Forest Productivity, Plum Creek Timber Company, Watkinsville, GA; K. Johnsen, Project Leader, USDA Forest Service, Southern Research Station, Research Triangle Park, NC; T. McDonald, Associate Professor, Biosystems Engineering Department, Auburn University, Auburn, AL; K. McLeod, Associate Research Ecologist, Savannah River Ecology Laboratory, University of Georgia, Aiken, SC; E. Nelson, Principal Scientist, Environmental Sciences and Technology Department, Savannah River Technology Center, New Ellenton, SC; D. Robison, Associate Professor, Department of Forestry, North Carolina State University, Raleigh, NC; R. Rummer, Project Leader, USDA Forest Service, Southern Research Station, Auburn, AL; F. Sanchez, Team Leader for the Soils Productivity Unit, USDA Forest Service, Southern Research Station, Research Triangle Park, NC; J. Stanturf, Project Leader, USDA Forest Service, Southern Research Station, Athens, GA; B. Stokes, National Program Leader for Forest Operations Research, Vegetation Management and Protection Research, Washington, DC; C. Trettin, Project Leader, USDA Forest Service, Southern Research Station, Charleston, SC; J. Tuskan, Senior Scientist, Environmental Sciences Division, Oak Ridge National Laboratory, Oak Ridge, TN; L. Wright, Bioenergy Systems Group Leader, National Bioenergy Center, Oak Ridge National Laboratory, Oak Ridge, TN; and S. Wullschleger, Senior Staff Scientist, Environmental Sciences Division, Oak Ridge National Laboratory, Oak Ridge, TN.

Cover Photo: Aerial photograph of Short Rotation Woody Crop Project at the Savannah River Site, near Aiken. SC. Individual plots are evident within each of the five large blocks. Surrounding longleaf and loblolly pine plantations represent the cover types removed prior to installing the multi-species research experiment testing forest growth response to a range of nutrient and soil moisture treatments.

The use of trade or firm names in this publication is for reader information and does not imply endorsement of any product or service by the U.S. Department of Agriculture or other organizations represented here.

\section{PESTICIDE PRECAUTIONARY STATEMENT}

This publication reports research involving pesticides. It does not contain recommendations for their use, nor does it imply that the uses discussed here have been registered. All uses of pesticides must be registered by appropriate State and/or Federal agencies before they can be recommended.

CAUTION: Pesticides can be injurious to humans, domestic animals, desirable plants, and fish or other wildlife if they are not handled or applied properly. Use all herbicides selectively and carefully. Follow recommended practices for the disposal of surplus pesticides and their containers.

January 2004

Southern Research Station

P.O. Box 2680

Asheville, NC 28802 


\title{
Production of Short-Rotation Woody Crops Grown with a Range of Nutrient and Water Availability: Establishment Report and First-Year Responses
}

\author{
M.D. Coleman, D.R. Coyle, J. Blake, K. Britton, M. Buford, R.G. Campbell, J. Cox, \\ B. Cregg, D. Daniels, M. Jacobson, K. Johnsen, T. McDonald, K. McLeod, E. Nelson, \\ D. Robison, R. Rummer, F. Sanchez, J. Stanturf, B. Stokes, C. Trettin, J. Tuskan, \\ L. Wright, and S. Wullschleger
}

\begin{abstract}
Many researchers have studied the productivity potential of intensively managed forest plantations. However, we need to learn more about the effects of fundamental growth processes on forest productivity; especially the influence of aboveground and belowground resource acquisition and allocation. This report presents installation, establishment, and first-year results of four tree species (two cottonwood clones, sycamore, sweetgum, and loblolly pine) grown with fertilizer and irrigation treatments. At this early stage of development, irrigation and fertilization were additive only in cottonwood clone ST66 and sweetgum. Leaf area development was directly related to stem growth, but root production was not always consistent with shoot responses, suggesting that allocation of resources varies among treatments. We will evaluate the consequences of these early responses on resource availability in subsequent growing seasons. This information will be used to: (1) optimize fiber and bioenergy production; (2) understand carbon sequestration; and (3) develop innovative applications such as phytoremediation; municipal, industrial, and agricultural wastes management; and protection of soil, air, and water resources.
\end{abstract}

Keywords: Allocation, fertigation, fine-root growth, intensive management, interspecific comparisons, leaf area.

\section{Introduction}

Intensive management practices now lead to large productivity gains in forest plantations. Practices used to grow short-rotation woody crops include selection of superior genetic material, intensive site preparation, competition and pest control, irrigation, and fertilization (Allen and others 1990, Borders and Bailey 2001, Ceulemans and others 1992, Dickmann and Stuart 1983, Heilman and Stettler 1986, Linder and others 1987, Stanturf and others 2001, Steinbeck and Skinner 1985, Tuskan 1998, Yin and Sedjo 2001). When using intensive culture techniques for such large productivity gains, process-level understanding is essential for making informed plantation management decisions. Ecophysiological research has provided an understanding of the relationship between stem growth and such processes as light interception, uptake of water and nutrients, and carbon metabolism (Cannell 1989, Landsberg and Gower 1997); but there is still much to learn. For instance, few complete carbon and nutrient budgets exist that include both aboveground and below- ground components for any forest type (Gower and others 1992, Vogt 1991). Without this information it is difficult to assess rudimentary questions of nutrient requirements, carbon storage, or carbon and nutrient acquisition. There also is poor understanding of belowground processes, allocation of carbon and nutrients within the plant, and acquisition of available nutrients from the soil, despite the clear evidence that both light interception and nitrogen availability are positively correlated with productivity (Cannell and Dewar 1994, Cannell and others 1988, Vose and Allen 1988). Information on resource allocation, root production, and nutrient acquisition is critical to understanding nutritional controls over productivity, as well as the impact of nutrition on essential root-mediated processes such as carbon assimilation and transpiration.

We installed a set of intensively managed stands to clarify carbon and nutrient mass balance and to define critical processes controlling tree-growth response to resource availability. We established a range of nutrient and water availability levels resulting in different levels of productivity in five tree genotypes [two eastern cottonwood (Populus deltoides Bartr.) clones (ST66 and S7C15), sycamore (Platatus occidentalis L.), sweetgum (Liquidambar styraciflua L.), and loblolly pine (Pinus taeda L.)]. These productivity levels also relate to resource acquisition and allocation of carbon and nitrogen both aboveground and belowground.

Throughout the rotation we will measure aboveground and belowground tree growth, nutrient accumulation, resource allocation, water use, and cycling of carbon and essential mineral nutrients in the plant and soil system. Hypothetical plant and environmental controls over productivity will be tested with growth process models. In summarizing the establishment of this long-term study, this report presents site conditions, treatments, and initial growth responses. As the study continues, we will report on growth, carbon and nutrient allocation, canopy development, leaf-level physiology, whole-tree transpiration, and fine-root production and turnover. 


\section{Materials and Methods}

\section{Site Description}

The experimental plot is located on the U.S. Department of Energy's Savannah River Site, a national environmental research park near Aiken, SC, in the Carolina sandhills physiographic region ( $33^{\circ} 23^{\prime} \mathrm{N}$.; $81^{\circ} 40^{\prime}$ E.) (fig. 1). The climate is humid continental with warm summers, mild winters, and an average annual temperature of $17.9^{\circ} \mathrm{C}$. Average minimum temperature in January is $1.4^{\circ} \mathrm{C}$; average maximum temperature in July is $32.8^{\circ} \mathrm{C}$. Growing season potential evaporation rates average 0.52 $\mathrm{cm} /$ day (U.S. Department of Commerce, National Oceanographic and Atmospheric Administration 1993, 1997).
A soil survey conducted in December 1998 identified five different soil series in two soil orders on the 40-ha site (fig. 2). The predominate soil is of the Blanton soil series, which developed in siliceous sand originating from Tertiary period beach deposits, and is classified as thermic Grossarenic Paleudults. An argillic subsoil occurs between 120 and $200 \mathrm{~cm}$ across the site, but the $105-\mathrm{cm}$ soil depth monitored for the described experiment is above this subsoil across the entire study site.

Previous vegetation was pine plantations with a sparse upland oak (Quercus spp.) understory. The eastern portion of the site contained pulp-quality loblolly pine planted in 1988, while the western portion contained pole-timber quality longleaf pine (P. palustris Mill.) planted in 1964. Stands were harvested in April through May of 1999.

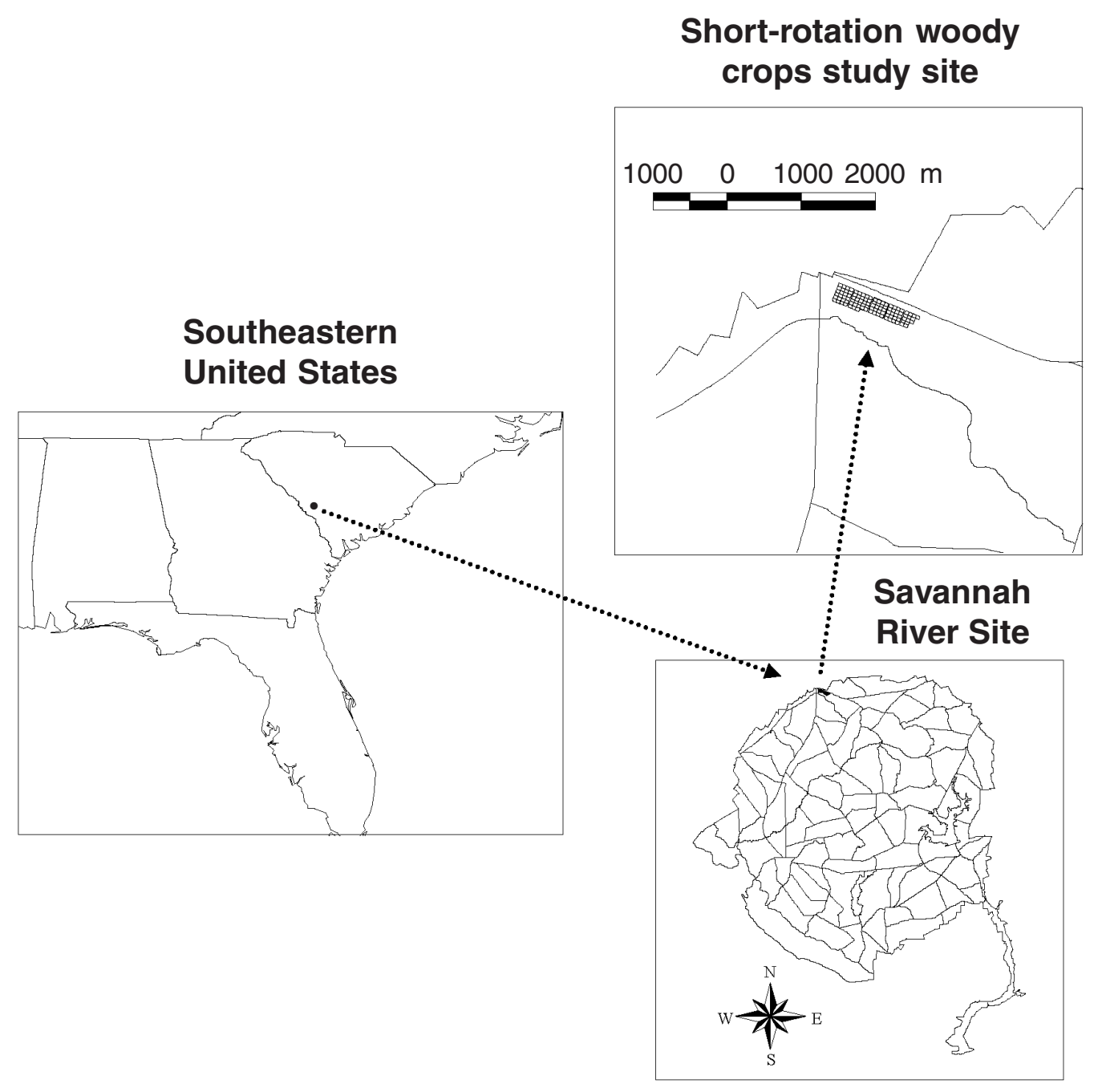

Figure 1-Location of the short-rotation woody crops study site operated by the U.S. Department of Agriculture Forest Service at the Savannah River Site near Aiken, SC (332' N. $81^{\circ} 40^{\prime}$ E.). 


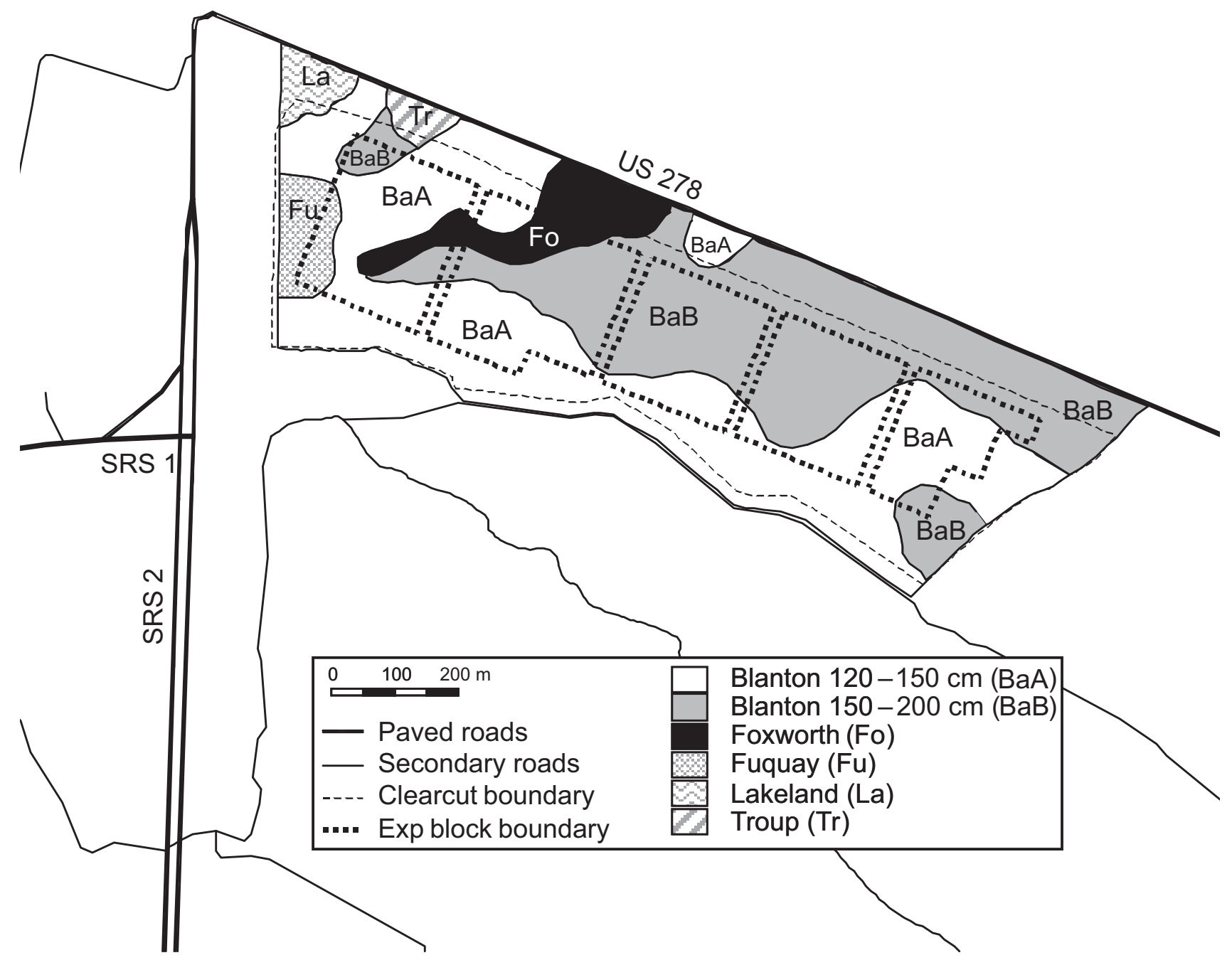

Figure 2-Soil survey of the short-rotation woody crops study site (Personal Communication. 1998. Dennis DeFrancesco, Soil Scientist, USDA Natural Resources Conservation Service, 301 University Ridge, Suite 4900, Greenville, SC 29601). Ultisols including Blanton, Fuquay, and Troup series occur within the study area. Entisols of the Lakeland and Foxworth series also occur. Blanton soils with subsoil depth of 102 to $152 \mathrm{~cm}$ were separated from those having depths from 150 to $203 \mathrm{~cm}$. Refer to http://www.ortho.ftw.nrcs.usda.gov/osd/dat/B/

BLANTON.html for a complete description of Blanton soils. The Foxworth series included in the study area is similar to Blanton except that it is sandy throughout the $203-\mathrm{cm}$ profile.

\section{Site Preparation}

Site preparation consisted of debris removal, tilling, and site amendments. We piled the slash measuring $>15 \mathrm{~cm}$ in diameter and the debarking debris that remained following the harvesting of research plots. An RS-500 Reclaimer/ Stabilizer (CMI Corp., Oklahoma City) (fig. 3) prepared the 21.9-ha area, pulverizing and incorporating the remaining debris, including stumps, to a depth of $30 \mathrm{~cm}$. We applied dolomite lime at a rate of $3.4 \mathrm{Mg} / \mathrm{ha}$ to achieve a target soil $\mathrm{pH}$ of 6.5. Finally, we pulled a Rome disc in two directions and planted winter rye for erosion control.

\section{Field Layout and Experimental Design}

Treatment plots were 0.22 ha (fig. 4). Tree spacing was 2.5 by $3 \mathrm{~m}$ for a planting density of 1,333 trees/ha so that 294 trees made up each treatment plot. Each treatment plot contained a central 0.04-ha measurement plot containing 54 trees, and large end borders served as harvest plots for destructive sampling. The border between the edge of the 


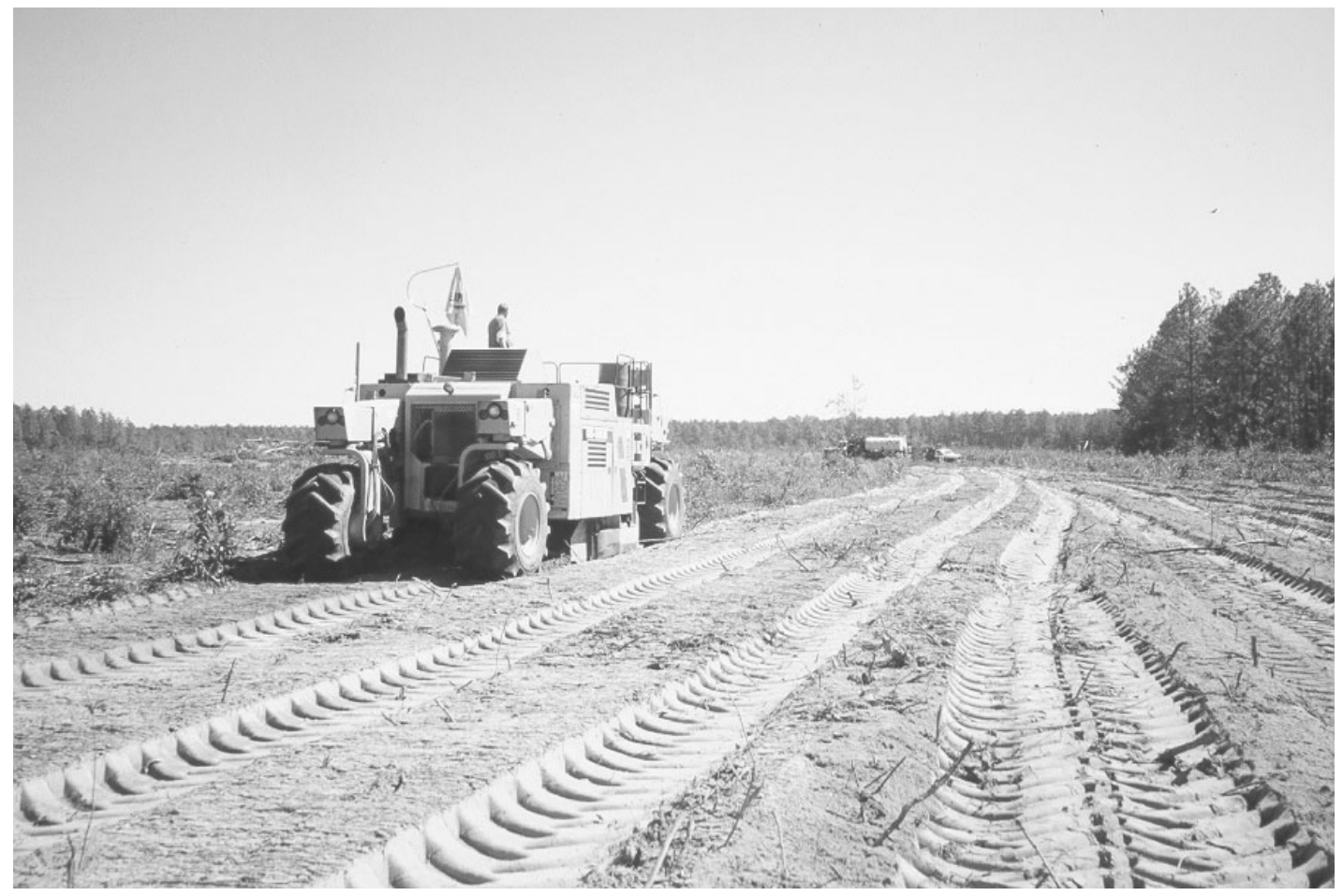

Figure 3-An RS-500 Reclaimer/Stabilizer (CMI Corp., Oklahoma City) prepared the site following shearing and raking. Remaining litter, vegetation, and stumps were ground and incorporated into the top $30 \mathrm{~cm}$ of soil in one pass. Cost was comparable to stump removal.

treatment plot and the measurement plot was $>12 \mathrm{~m}$, minimizing interaction among nutrient treatment plots. The six trees at the center of each plot were used for repeated growth measurements.

The experiment tested discrete treatment differences using analysis-of-variance (ANOVA) and determined response surfaces by regression. This robust composite method accommodates tradeoffs among experimental designs and operational constraints. The core experiment was a threeway, complete factorial, split-plot design including fertilization, irrigation, and five tree genotypes (fig. 5). We split genotype whole plots into four subplots, which included fertilization and irrigation treatments. We randomly assigned genotypes to whole plots and treatments to subplots. This experiment tested main effects and interactions among species, irrigation, and fertilization. However, the core factorial ANOVA experiment could not define the fertilizer response function that was required for modeling. We defined the fertilizer response function by including nonreplicated intermediate fertilizer levels for the primary irrigation treatment. Increasing the number of fertilizer levels in the replicated ANOVA experiment would have required greater resources and placed undue emphasis on lessdesired treatment combinations as nonirrigated cottonwood or irrigated pine. The regression approach tests important treatment combinations on nonreplicated plots, and efficiently defines response surfaces in agricultural experiments (Anderson and McLean 1974, Box and Draper 1987, Gomez and Gomez 1984). The regression approach used less than half the plot count required for the full factorial design, but more precisely defined the response surface.

\section{Tree Stock and Planting Information}

We tested five tree genotypes in this experiment: two eastern cottonwood clones (ST66, Issaquena County, MS, and S7C15, Brazos County, TX); sycamore (Westvaco orchard run); sweetgum (Westvaco family WV340); and loblolly pine (International Paper family 7-56). Two cottonwood clones gave a broader genetic representation of the species than would have been possible with a single clone. Other species represented by a single half-sibling family had more genetic diversity than cottonwood. The cottonwood cuttings came from Crown Vantage (Fitler, MS), the pine seedlings from International Paper 


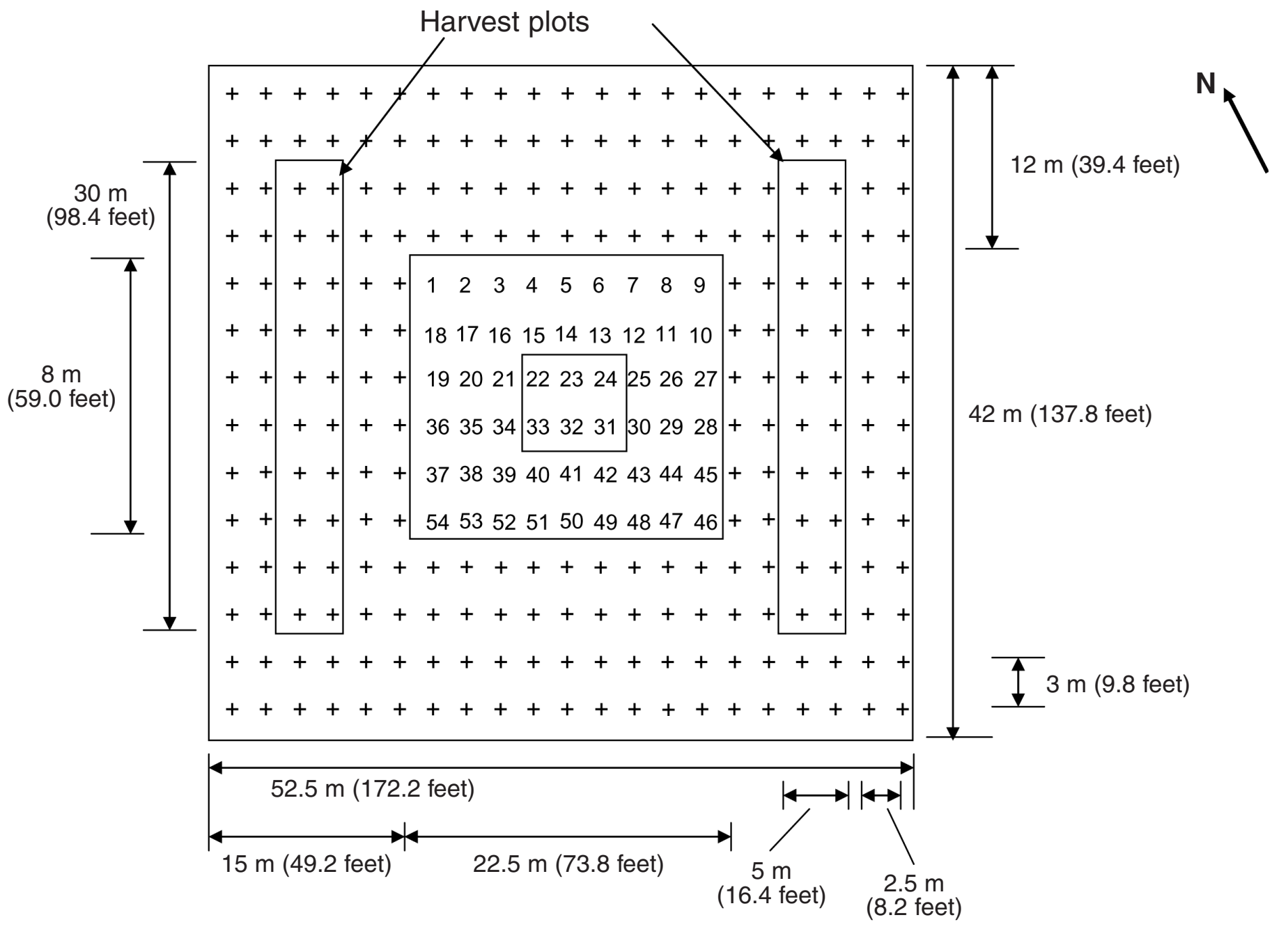

Figure 4-Individual treatment plot having 14 by 21 tree rows (294 trees). A central measurement and two destructive harvest plots were included in each plot. Periodic height, diameter, and leaf area measurements were taken on six central trees.

(Lumberton, NC), and the sycamore and sweetgum seedlings from Westvaco (Summerville, SC).

Nursery personnel lifted bare-root loblolly pine, sycamore, and sweetgum seedlings (1-0) in mid-January 2000 and we planted them during the first week of February 2000. Nursery personnel collected cottonwood cuttings (1- to 2 -cm diameter by 40 -cm long) from stool beds in early January 2000 . We held them at $3.3{ }^{\circ} \mathrm{C}$, and soaked them during the second week of April 2000 for at least 48 hours prior to planting using round metal dibbles ( 2 by $45 \mathrm{~cm}$ ).

\section{Irrigation Treatment}

Plots received either an irrigated or nonirrigated treatment using an automated drip irrigation system (B.B. Hobbs, Darlington, SC). The irrigated treatments (1 and 2, 5 through 10) (fig. 5) received $0.5 \mathrm{~cm} /$ day, 6 days a week (3 $\mathrm{cm} /$ week) from April to October in 2000, regardless of rainfall. Average regional daily evaporation for the period between April and October is $0.5 \mathrm{~cm} /$ day; therefore, the irrigation amount was designed to eliminate the evaporation deficit and ensure favorable soil moisture. In addition to precipitation, nonirrigated treatments ( 3 and 4 , 11 through 16) (fig. 5) received only enough water to 


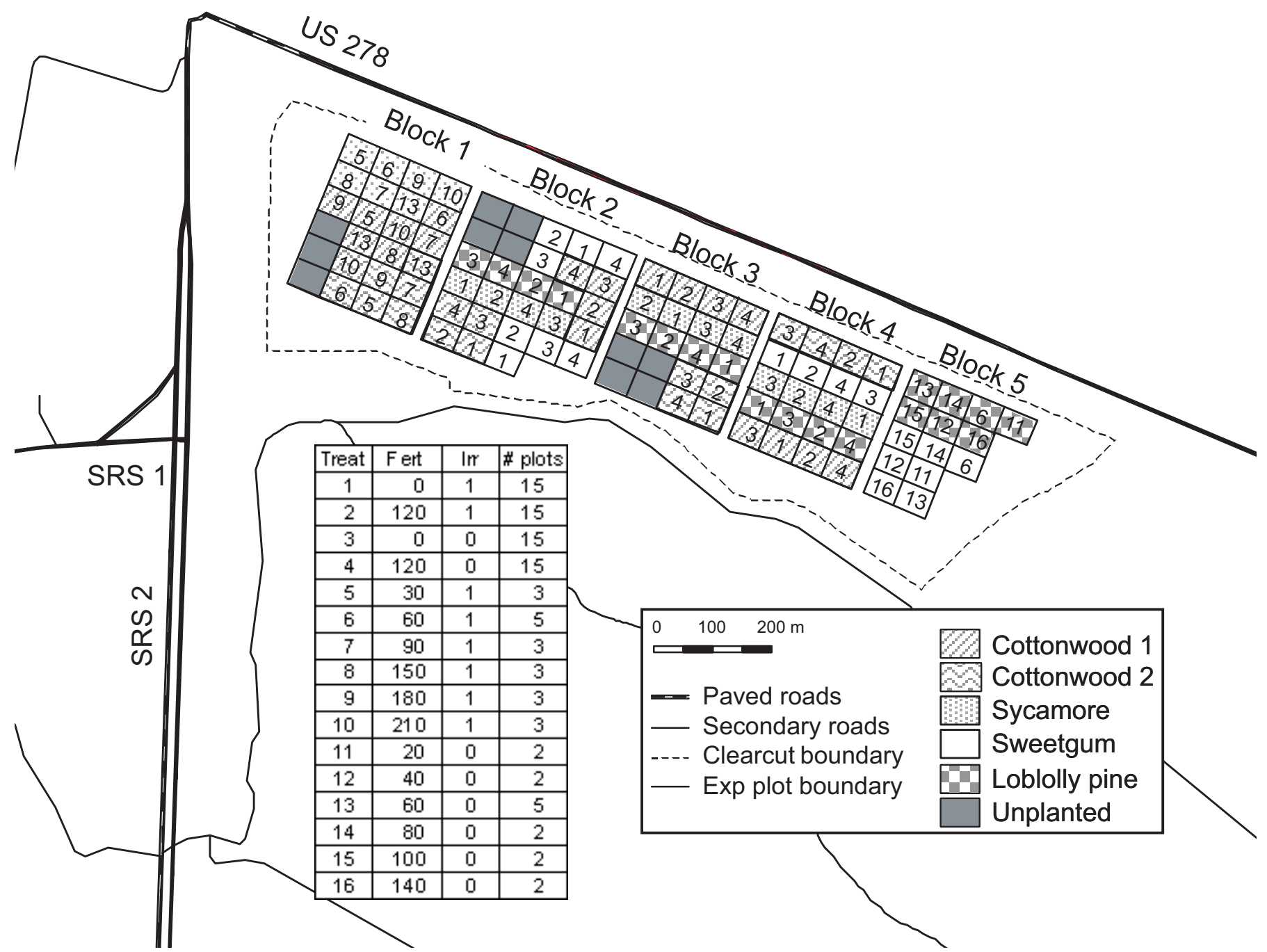

Figure 5-Treatments at the short-rotation woody crops study site. The 3 central analysis-of-variance blocks and the 2 peripheral regression blocks contain a total of 16 treatments of 5 tree genotypes. Treatments 1, 2, 3, and 4 were replicated in the central blocks for all genotypes. Block 1 includes irrigated treatments for cottonwood and sycamore, and block 5 includes nonirrigated treatments for pine and sycamore. A range of nonreplicated fertilizer levels was applied in both blocks 1 and 5.

apply liquid fertilizer and flush lines in the most distant plot $(0.5 \mathrm{~cm} /$ week).

\section{Fertilizer Treatment}

We applied fertilizer weekly to both irrigated and nonirrigated treatments through the automated drip irrigation system. The concentrated liquid fertilizer used was 7-7-7 nitrogen-phosphorus-potassium (N-P-K) plus 0.22 percent boron $(\mathrm{B}), 0.01$ percent copper $(\mathrm{Cu}), 0.05$ percent manganese (Mn), 0.001 percent molybdenum (Mo), and 0.03 percent zinc $(\mathrm{Zn})$. Starting in April we divided the annual amount into 26 equal doses applied weekly. Site preparation lime applications met calcium $(\mathrm{Ca})$ and magnesium $(\mathrm{Mg})$ requirements.

We included two fertilizer levels in the replicated ANOVA experiment: a nonfertilized control and $120 \mathrm{~kg} \mathrm{~N} / \mathrm{ha} / \mathrm{year}$. The NUTREM model (Anonymous 1997) was used to consider nutrient uptake requirements for loblolly pine. We supplied the model with data from an 11-year-old stand producing $13 \mathrm{Mg} / \mathrm{ha} /$ year of stem dry weight (Albaugh and others 1998). The "soil resource uptake" value output from the model was $118 \mathrm{~kg} \mathrm{~N} / \mathrm{ha} /$ year. Four-year-old hybrid 
poplars producing $14 \mathrm{Mg} / \mathrm{ha} /$ year contained $116 \mathrm{~kg} \mathrm{~N} / \mathrm{ha} /$ year aboveground (Heilman and Stettler 1986, Nelson and others 1987). Clones producing over twice this amount of wood will contain over $250 \mathrm{~kg} \mathrm{~N} / \mathrm{ha} /$ year aboveground (Heilman and Stettler 1986). In other fertilized forests, rates of $\mathrm{N}$ uptake exceed $400 \mathrm{~kg} \mathrm{~N} / \mathrm{ha} /$ year (Johnson 1992). Mineralization is expected to supply 20 to $80 \mathrm{~kg} \mathrm{~N} / \mathrm{ha} /$ year (Pastor and others 1984, Reich and others 1997); therefore, the $120-\mathrm{kg}-\mathrm{N} / \mathrm{ha} /$ year application rate we used exceeded the amount of $\mathrm{N}$ required for pine, but was low for fastgrowing hardwoods. Applying a relatively high rate for pine and relatively low rate for hardwoods was justified because we applied a common fertilizer treatment level to all genotypes. In the ANOVA experiment an optimal fertilizer rate was not critical because the regression experiment was designed to identify the optimal nutrient amendment rate.

For the primary irrigation treatment, we applied six additional fertilizer levels to nonreplicated plots for each species; i.e., irrigated cottonwood and sycamore, nonirrigated sweetgum and pine (fig. 5). Cottonwood and sycamore received three levels below and three levels above $120 \mathrm{~kg} \mathrm{~N} / \mathrm{ha} /$ year ANOVA level. Loblolly pine and sweetgum received five levels below and one above $120 \mathrm{~kg}$ $\mathrm{N} / \mathrm{ha} /$ year. The highest fertilizer levels were expected to exceed optimum nutrition rates. To help define the regression curve for the secondary irrigation treatment, we included a single plot at $60 \mathrm{~kg} \mathrm{~N} / \mathrm{ha} /$ year for each species. To ensure nutritional balance, we maintained other nutrients in proportion with $\mathrm{N}$ as amendment rates varied.

During the 2000 growing season, fertilizer rates were onethird of the target rate based on nutrient requirement. The proportion of the final rate will increase during the first 3 to 5 establishment years because demand is less during establishment. For cottonwood and sycamore, we applied one-third the designated level in the first year; i.e., $40 \mathrm{~kg}$ $\mathrm{N} / \mathrm{ha} / \mathrm{year}$ for ANOVA plots, we will apply two-thirds in the second year and the full treatment rate thereafter. For loblolly pine and sweetgum, we will apply one-third of the treatment rate the first 2 years, two-thirds will be applied the third and fourth years, and the full treatment subsequently. The increase will approximate the initial low nutrient demand of young plantations and the maximum demand following establishment.

\section{Pest and Weed Control}

Pest and weed control were applied as needed. Weed control treatments included a glyphosate (Roundup ${ }^{\circledR}$ Pro, Monsanto Corp., St. Louis, MO) application to cottonwood plots
2 weeks prior to planting and an oxyflourfen $\left(\mathrm{Goal}^{\circledR} 2 \mathrm{XL}\right.$, Rohm and Haas Co., Philadelphia) application to bare-root species within 1 month postplanting. Oxyflourfen was applied to cottonwoods 5 to 8 days postplanting. We directed glyphosate applications in rows between irrigation lines during the last week of June and the second week of September. We tilled weeds between irrigation rows during the first week of August. We applied Hydramethylnon $\left(\right.$ Amdro $^{\circledR}$, American Cyanamid Co, Parsippany, NY) and dicofol (Kelthane ${ }^{\circledR}$ 50, Rohm and Haas Co., Philadelphia) to cottonwood plots for fire ant and leaf mite control, respectively; we applied permethrin $\left(\right.$ Ambush $^{\circledR}$, Zeneca Ag Products, Wilmington, DE) to loblolly pine plots for tip moth control. Pest monitoring determined the need for insecticide applications.

\section{Minirhizotrons}

In March and April 2000, we installed 5-cm-diameter acrylic minirhizotrons at a $45^{\circ}$ angle to a depth of $1.05 \mathrm{~m}$ to measure fine-root growth. We placed five minirhizotron tubes per plot at one of five predetermined locations around five trees (fig. 6) in each loblolly pine and cottonwood ST66 plot within ANOVA blocks (treatments 1 to 4). One of the five locations was assigned to a randomly selected tree within the measurement plot. We painted the exposed minirhizotron ends black to prevent light from reaching roots, and then white to avoid heat buildup. We secured tubes in place using $5-\mathrm{cm}$ pipe hangers bolted to a $1.3-\mathrm{cm}$ metal conduit driven $90 \mathrm{~cm}$ into the ground. We constructed tube caps by gluing a $35-\mathrm{cm}$ long piece of pipe insulation (designed for 1.9-cm copper pipe) inside the bottom of a 355-ml aluminum beverage can (with top removed). Pipe insulation extended belowground inside the tube to prevent light penetration and minimize heat transfer from the surface to the roots. The aluminum can protected the tube end from moisture.

We used a video camera (BTC2; Bartz Technology, Santa Barbara, CA) equipped with an indexing handle to collect observations. One-hundred-four frames $\left(180.96 \mathrm{~mm}^{2}\right)$ were monitored per tube for a total of $188.2 \mathrm{~cm}^{2} /$ minirhizotron. This monitored area, 75 percent of captured image area (13.5 by $18 \mathrm{~mm}$ ), allows image rectification. We captured digital video images in the field (ICAP Bartz Technology, Santa Barbara, CA) and quantified them using Rootracker (Duke University, Durham, NC). We measured new roots appearing on the outside upper surface of the acrylic tube. Because we tried to eliminate competing vegetation, we assumed all observed roots to be from plantation trees. 


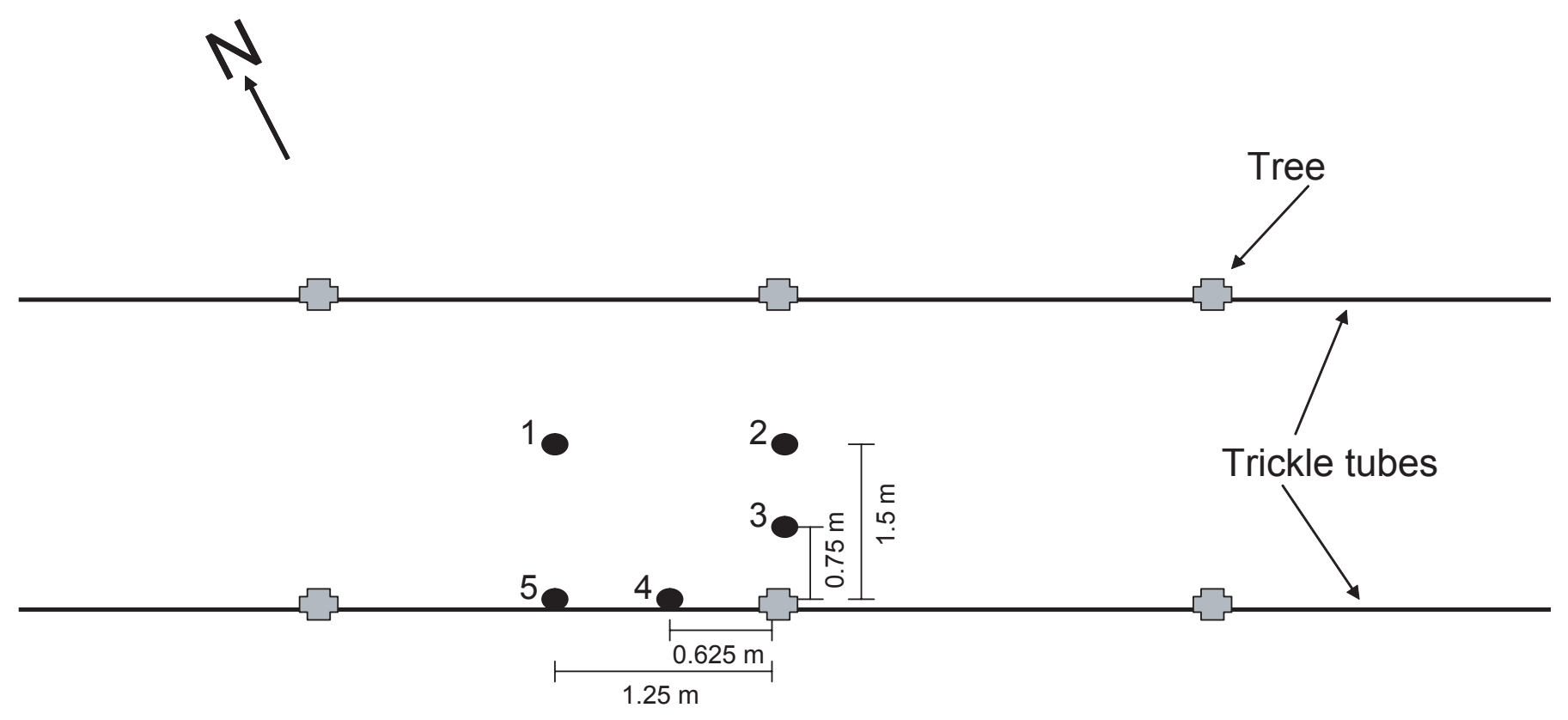

Figure 6-Five minirhizotron locations (dark circles) adjacent to randomly selected trees in cottonwood ST66 and loblolly pine measurement plots. Locations are selected to define expected variation in root production due to tree and drip-tube proximity. Locations 1 and 2 vs. 4 and 5 contrast the drip-tube proximity effect. Locations 3 and 4 vs. 1,2, and 5 contrast the tree proximity effects.

\section{Environmental Monitoring}

A weather station (Campbell Scientific, Inc., Logan, UT) installed in a cleared area (50 m west of block 1$)$ recorded hourly temperature, solar radiation, soil moisture, soil temperature, relative humidity, rainfall, and wind speed and direction. We calculated potential evapotranspiration with hourly weather data (Van Bavel 1966). Additional data loggers recorded soil temperature measurements hourly (Onset Computer Corp., Pocasset, MA) at eight locations and four depths per location $(0,15,45$, and 105 $\mathrm{cm}$ ). We also installed rain gauges (Tru-Chek, Albert Lea, $\mathrm{MN})$ at 12 locations across the site and recorded data after each rain event to evaluate distribution.

We measured soil moisture weekly at a $15-\mathrm{cm}$ depth in each plot using a TRIME-FM Mobile Moisture Meter (IMKO, Ettlingen, Germany). Soil moisture was measured under drip irrigation lines and between drip lines in each plot.

\section{Soil Samples}

In April 1999 before harvesting preexisting vegetation, we collected soil samples at 40 locations on a 100 - by $100-\mathrm{m}$ grid for 0- to 15-, 15- to 45-, and 45- to 105-cm depths. In April 2000 following planting, we sampled soil from each plot at the same depths. The Clemson University
Agricultural Extension Soil and Plant Analysis Laboratory conducted soil analyses. They acid-extracted samples ( 0.05 $\mathrm{N} \mathrm{HCl}$ and $0.025 \mathrm{~N} \mathrm{H}_{2} \mathrm{SO}_{4}$ ) and analyzed for $\mathrm{P}, \mathrm{K}, \mathrm{Ca}, \mathrm{Mg}$, $\mathrm{Zn}, \mathrm{Mn}, \mathrm{Cu}, \mathrm{B}$, and sodium (inductively coupled plasma atomic emmission spectrometer). They determined organic matter from loss on ignition and measured soil $\mathrm{pH}$ and buffer $\mathrm{pH}$ (8.0) for evaluating cation exchange capacity, base saturation, and lime requirements (Sims 1996). They also determined soil texture on samples collected in April 1999.

\section{Growth Measurements}

We recorded height and root-collar diameter monthly on the six central trees per plot. Where multiple shoots or trees were present, we measured the tallest.

\section{Mortality}

We quantified cottonwood and loblolly pine mortality on May 25, 2000. We classified dead cottonwoods as nonrooters (having a dead shoot over $2.5 \mathrm{~cm}$ in length), herbicide damaged (dead bud or shoot under $2.5 \mathrm{~cm}$ in length), or previously dead (no shoot growth). Pine mortality was classified as pine weevil (Pales and Hylobius spp., Coleoptera: Curculionidae) feeding (dead tree; girdling present) or previously dead because of stock quality or planting (dead tree; no weevil girdling). We observed no mortality in sweetgum or sycamore. 


\section{Leaf Area}

We measured leaf area monthly in each plot from June to October 2000. Due to rapid growth we modified the number of trees measured at each sampling event. Leaf area estimates for secondary stems were based on allometry of the main stems. For cottonwoods, we measured lengths of all fully expanded leaves $>3 \mathrm{~cm}$ in length (Leaf Plastochron Index =0) (Larson and Isebrands 1971) on the six centermost trees per plot in July and one tree per plot in August, September, and October. For sycamore, we recorded the length of every leaf in June. Later, we measured all sycamore and sweetgum branch diameters and all leaf lengths for the terminal and three representative branches. We measured six sycamore and sweetgum trees per plot in June and July and one tree per plot in August, September, and October. For loblolly pine in June and July, we measured the diameter of all branches and the terminal for six trees per plot. On three trees per plot, we counted all fascicles on three representative branches of known diameter and measured lengths of three fascicles on each representative branch. We reduced sampling to one tree per plot in August, September, and October.

Coinciding with field measurement of leaf lengths we destructively sampled leaves to determine leaf length-toprojected-area relationships and specific leaf area. In June and July, we collected three representative hardwood leaves and six pine fascicles per plot that encompassed the entire range of leaf sizes. In August, September, and October, 9 leaves (or 18 fascicles) per species were collected in each plot. We measured leaf length, recorded corresponding leaf area using a Delta-T area meter (Decagon Devices, Inc., Pullman, WA), and recorded dry weight after leaves had ovendried $\left(65^{\circ} \mathrm{C}\right)$ for 4 days.

We predicted representative branch-leaf area by summing leaf areas calculated from leaf length-to-area relationships. In turn, we predicted whole-tree leaf area by summing branch areas calculated from branch diameter-to-branchleaf area estimates. The ratio of whole-tree leaf area to basal diameter was used to determine leaf area index (LAI) based on tree stocking and mortality.

\section{Foliar Nutrient Analysis}

In the first week of July 2000, we collected hardwood leaf samples. One sunlit, recently matured leaf was collected from each of the 54 measurement-plot trees. During midJanuary 2001, we collected pine leaf samples. Five representative fascicles were collected from the last fully expanded flush of each measurement tree. For each plot, we combined ovendried $\left(65^{\circ} \mathrm{C}\right)$ ground samples to pass a 40 mesh screen, and determined foliar $\mathrm{N}$ concentration by dry combustion (Carlo-Erba model NA-1500).

\section{Statistical Analysis}

We analyzed data for the core experiment with a randomized complete block design using a standard linear model of the form: $x_{i j}=\mu+\alpha_{i}+\beta_{j}+\varepsilon_{i j}$

where

$\mu=$ represents the overall mean

$\alpha_{i}=$ stands for the treatment effect ( $i=1$ to 4 )

$\varepsilon_{i j}=$ for the block effect ( $j=1$ to 3 ) with $\varepsilon_{i j}$ being uncorrelated random error and used as the denominator in $F$-tests for treatment and block effects.

We separated treatment means with Tukey's Studentized Range Test (HSD) and orthogonal contrasts. All analyses were conducted independently for each genotype. We fitted fertilizer response surfaces to second-order polynomials and compared regression equations for leaf area as a function of diameter by testing for coincidence and slope differences among treatments (Kleinbaum and Kupper 1978). SAS was used for all analyses (SAS Institute, Inc., Cary, NC).

\section{Results and Discussion}

\section{Climate Data}

Weather data for the 2000 growing season showed warmer and drier conditions than normal (table 1). However, compared with average pan evaporation values, Penman calculations of potential evaporation for $2000 \mathrm{did}$ not reflect drier, warmer conditions. Nonetheless, Penman calculations directly relate to evaporative demand and, therefore, can estimate evapotranspiration for irrigation scheduling.

\section{Soil Texture and Water-Holding Capacity}

Soil texture and water-holding capacity appear in table 2 . The soil classification is sand from the surface to a $105-\mathrm{cm}$ depth of samples collected because, on average, it contains $>90$ percent sand. However, 10 out of 40 samples between 45 and $105 \mathrm{~cm}$ were classified as loamy sand due to increased silt and clay content. To evaluate soil water supply capacity for this site, we calculated water-holding 
Table 1-Comparison of 30-year average weather data collected in Blackville, SC, with weather data collected at the short-rotation woody crops study site in 2000

\begin{tabular}{|c|c|c|c|c|c|c|c|c|c|c|c|c|}
\hline Weather data & Jan. & Feb. & Mar. & Apr. & May & June & July & Aug. & Sept. & Oct. & Nov. & Dec. \\
\hline & \multicolumn{12}{|c|}{ 30-year average } \\
\hline Avg. max. temp. $\left({ }^{\circ} \mathrm{C}\right)$ & 13.7 & 15.2 & 20.0 & 24.8 & 28.7 & 31.8 & 32.8 & 32.3 & 29.7 & 24.9 & 19.7 & 15.3 \\
\hline Avg. min. temp. $\left({ }^{\circ} \mathrm{C}\right)$ & 1.4 & 2.8 & 6.8 & 11.2 & 15.7 & 19.4 & 21.4 & 21.1 & 18.0 & 12.4 & 6.8 & 3.6 \\
\hline Rainfall $(\mathrm{cm})$ & 11 & 11 & 13 & 9 & 11 & 11 & 12 & 12 & 10 & 6 & 6 & 9 \\
\hline $\begin{array}{l}\text { Avg. pan evaporation } \\
(\mathrm{cm} / \mathrm{day})^{\mathrm{a}}\end{array}$ & 0.17 & 0.21 & 0.36 & 0.49 & 0.59 & 0.65 & 0.66 & 0.53 & 0.46 & 0.29 & 0.19 & 0.15 \\
\hline \multirow[t]{2}{*}{ Evaporation deficit } & -5.7 & -5.1 & -1.8 & 5.7 & 9.3 & 8.5 & 8.5 & 4.4 & 3.8 & 3.0 & -0.3 & -4.4 \\
\hline & \multicolumn{12}{|c|}{2000} \\
\hline Avg. max. temp. $\left({ }^{\circ} \mathrm{C}\right)$ & $-^{b}$ & - & - & - & 28.9 & 32.5 & 32.8 & 31.7 & 27.5 & 25.1 & 17.6 & 8.8 \\
\hline Avg. min. temp. $\left({ }^{\circ} \mathrm{C}\right)$ & - & - & - & - & 16.8 & 19.1 & 19.1 & 20.4 & 17.8 & 10.5 & 5.6 & -1.5 \\
\hline Rainfall $(\mathrm{cm})$ & - & - & - & 0.1 & Trace & 8.8 & 9.9 & 8.5 & 18.0 & 8.4 & 4.8 & 4.4 \\
\hline $\begin{array}{l}\text { Avg. calculated } \\
\text { evaporation }(\mathrm{cm} / \text { day })\end{array}$ & - & - & - & - & 0.63 & 0.58 & 0.57 & 0.48 & 0.38 & 0.39 & 0.20 & 0.12 \\
\hline Evaporation deficit & - & - & - & - & 19.6 & 8.4 & 7.8 & 6.5 & -6.6 & 3.8 & 1.3 & -0.6 \\
\hline
\end{tabular}

${ }^{a}$ Pan evaporation values from Blackwell, SC, are compared with potential evaporation calculated from weather data (Van Bavel 1966).

${ }^{b}$ Data were not collected before cottonwood cuttings were planted in late April.

Source: U.S. Department of Commerce, National Oceanographic and Atmospheric Administration (1993, 1997).

Table 2-Soil texture and water-holding capacity for core experiment at the short-rotation woody crops study site

\begin{tabular}{|c|c|c|c|c|c|c|c|}
\hline Depth & Sand & Silt & Clay & $\begin{array}{c}\text { Field } \\
\text { capacity }\end{array}$ & $\begin{array}{c}\text { Wilting } \\
\text { point }\end{array}$ & \multicolumn{2}{|c|}{ Available water } \\
\hline $\mathrm{cm}$ & \multicolumn{3}{|c|}{ - - - - percent - - - - } & \multicolumn{3}{|c|}{$\ldots-\ldots \mathrm{cm}^{3} / \mathrm{cm}^{3}-\ldots$} & mm/layer \\
\hline $0-15$ & 92.9 & 4.7 & 2.4 & 0.11 & 0.04 & 0.068 & 10 \\
\hline $15-45$ & 92.0 & 5.5 & 2.5 & 0.11 & 0.04 & 0.070 & 21 \\
\hline $45-105$ & 90.0 & 5.5 & 4.5 & 0.13 & 0.06 & 0.074 & 45 \\
\hline
\end{tabular}

Mean of 40 soil samples collected in April 1999.

capacity based on textural properties (Saxton and others 1986). Available water between field capacity and permanent wilting point was similar for each depth due to consistent sand content.

Available water, expressed on a soil depth basis, can be compared to evaporative demand to determine soil water supply capacity. Peak potential evaporation for this site is 5 to $6 \mathrm{~mm} /$ day (table 1). The upper $45 \mathrm{~cm}$ of this coarse textured soil will store only $31 \mathrm{~mm}$ of water, a 5- to 6-day supply during peak evaporation. The lower portion of the rooting volume (45 to $105 \mathrm{~cm}$ ) can supply an additional 8 to 9 days. Prior to using all the soil moisture supply, trees will begin to regulate water loss by closing stomata and abscising leaves. Without water input during peak evaporative demand, such water-loss regulation will affect growth before available soil moisture is exhausted within this 5- to 9-day period. 


\section{Soil Nutrients}

Prior to treatment applications, distinct depth gradients in soil nutrient concentration were evident from soil samples collected across the site. The upper layers of soil contained the greatest amount of nutrients corresponding with the highest levels of organic matter and cation exchange capacity (CEC) (tables 3 and 4). Nutrient levels, organic matter content, and CEC are naturally low in this sandy soil type. Prior to amendments, soil $\mathrm{pH}$ was below 5.0 across the site and required lime to raise the $\mathrm{pH}$ to acceptable levels for hardwoods ( $\mathrm{pH}$ 6.5). According to the Adams-Evans buffer method (Sims 1996), $3.36 \mathrm{Mg} / \mathrm{ha}$ of lime was required to bring the $\mathrm{pH}$ to 6.5. Lime applications improved soil $\mathrm{pH}$ especially in the upper layers, but it was still $0.75 \mathrm{pH}$ units below target levels, demonstrating the need for additional lime. Lime application and other site-preparation activities more than

Table 3-Soil nutrient content on the short-rotation woody crops study prior to and after lime application in March 2000

\begin{tabular}{|c|c|c|c|c|c|c|c|c|c|c|}
\hline Depth & $\begin{array}{l}\text { Organic } \\
\text { matter }\end{array}$ & $\mathrm{Ca}$ & $\mathrm{Mg}$ & $\mathrm{P}$ & $\mathrm{K}$ & $\mathrm{Zn}$ & $\mathrm{Mn}$ & $\mathrm{Cu}$ & $\mathrm{B}$ & $\mathrm{Na}$ \\
\hline \multirow[t]{2}{*}{$\mathrm{cm}$} & percent & ----- & $\cdots$ & - & $-\ldots$ & $k g / h a-$ & $-\ldots$ & $-\cdots--$ & $-\cdots$ & $-\ldots$ \\
\hline & \multicolumn{10}{|c|}{ Prior to lime application } \\
\hline \multirow[t]{2}{*}{$0-15$} & - & $202 \pm 41$ & $27 \pm 2$ & $3.4 \pm 2.8$ & $24.3 \pm 2.9$ & $1.9 \pm 0.9$ & $14 \pm 2$ & $0.9 \pm 0.3$ & $0.1 \pm 0.1$ & 一 \\
\hline & \multicolumn{10}{|c|}{ After lime application } \\
\hline $0-15$ & $1.40 \pm 0.27$ & $563 \pm 242$ & $176 \pm 79$ & $3.6 \pm 4.5$ & $19.1 \pm 6.5$ & $1.9 \pm 0.9$ & $20 \pm 10$ & $0.5 \pm 0.3$ & $0.3 \pm 0.1$ & $12 \pm 2$ \\
\hline $15-30$ & $1.31 \pm 0.29$ & $322 \pm 221$ & $87 \pm 83$ & $3.3 \pm 3.8$ & $22.9 \pm 7.3$ & $1.4 \pm 0.5$ & $20 \pm 10$ & $0.5 \pm 0.3$ & $0.3 \pm 0.1$ & $11 \pm 2$ \\
\hline $30-45$ & $0.88 \pm 0.29$ & $188 \pm 104$ & $46 \pm 24$ & $1.8 \pm 2.2$ & $18.4 \pm 6.0$ & $1.0 \pm 0.7$ & $14 \pm 9$ & $0.4 \pm 0.2$ & $0.2 \pm 0.1$ & $11 \pm 3$ \\
\hline $45-105$ & $0.59 \pm 0.31$ & $114 \pm 61$ & $28 \pm 14$ & $1.9 \pm 1.8$ & $12.8 \pm 3.6$ & $0.5 \pm 0.2$ & $5 \pm 5$ & $0.3 \pm 0.4$ & $0.2 \pm 0.1$ & $11 \pm 3$ \\
\hline
\end{tabular}

$\mathrm{Ca}=$ Calcium $; \mathrm{Mg}=$ magnesium $; \mathrm{P}=$ phosphorus $; \mathrm{K}=$ potassium $; \mathrm{Zn}=$ zinc $; \mathrm{Mn}=$ manganese $; \mathrm{Cu}=$ copper $; \mathrm{B}=$ boron; $\mathrm{Na}=$ sodium; - = no data . Mean \pm sem, $\mathrm{n}=95$.

Table 4-Soil pH and base saturation levels on the short-rotation woody crops study prior to and after lime application in March 2000

\begin{tabular}{|c|c|c|c|c|c|c|c|c|c|}
\hline \multirow[b]{2}{*}{ Depth } & \multirow[b]{2}{*}{ Soil pH } & \multirow[b]{2}{*}{ Buffer pH } & \multirow[b]{2}{*}{ CEC } & \multirow[b]{2}{*}{ Acidity } & \multicolumn{5}{|c|}{ Base saturation } \\
\hline & & & & & $\mathrm{Ca}$ & $\mathrm{Mg}$ & $\mathrm{K}$ & $\mathrm{Na}$ & Total \\
\hline $\mathrm{cm}$ & \multicolumn{9}{|c|}{ Prior to lime application } \\
\hline $0-15$ & \multicolumn{9}{|c|}{ After lime application } \\
\hline $0-15$ & $5.8 \pm 0.3$ & $7.72 \pm 0.06$ & $4.0 \pm 0.8$ & $2.2 \pm 0.4$ & $28.0 \pm 8.0$ & $14.6 \pm 4.7$ & $0.4 \pm 0.5$ & $0.6 \pm 0.5$ & $43.5 \pm 11.5$ \\
\hline $15-30$ & $5.4 \pm 0.4$ & $7.70 \pm 0.06$ & $3.4 \pm 0.8$ & $2.4 \pm 0.5$ & $18.4 \pm 8.2$ & $8.2 \pm 5.5$ & $0.9 \pm 0.3$ & $0.8 \pm 0.4$ & $28.3 \pm 12.9$ \\
\hline $30-45$ & $5.2 \pm 0.3$ & $7.77 \pm 0.06$ & $2.4 \pm 0.6$ & $1.8 \pm 0.5$ & $15.7 \pm 5.8$ & $6.5 \pm 3.1$ & $0.9 \pm 0.3$ & $1.0 \pm 0.3$ & $24.0 \pm 8.2$ \\
\hline $45-105$ & $5.0 \pm 0.2$ & $7.81 \pm 0.05$ & $1.9 \pm 0.6$ & $1.5 \pm 0.4$ & $12.2 \pm 4.4$ & $5.1 \pm 2.0$ & $0.9 \pm 0.3$ & $1.1 \pm 0.4$ & $19.4 \pm 6.3$ \\
\hline
\end{tabular}

$\mathrm{CEC}=$ Cation exchange capacity $; \mathrm{Ca}=$ calcium $; \mathrm{Mg}=$ magnesium; $\mathrm{K}=$ potassium $; \mathrm{Na}=$ sodium .

Mean \pm sem, $n=95$. 
doubled CEC, resulting in higher base saturation, mainly occupied by exchangeable $\mathrm{Mg}$. As the total base saturation increased with the improved CEC, the proportion of acidity decreased from 63.5 percent prior to liming to 55.3 percent afterward. Such results demonstrate the value of liming for improving soil nutrient-holding capacity.

\section{Soil Moisture}

Percent soil moisture was consistently higher under drip lines (fig. 7); between drip lines, soil moisture was consistently low for all treatments and species. This occurred even in

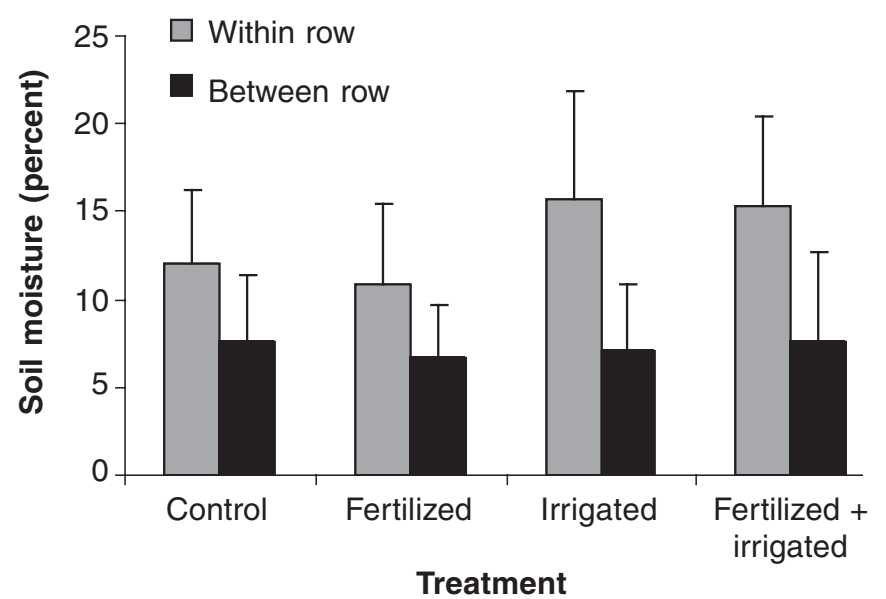

Figure 7-Mean soil moisture $(+\mathrm{SE}, \mathrm{n}=100)$ in response to irrigation and fertilization. Measurements were collected in analysis-of-variance plots from July through September 2000. Within-row measurements represent those taken along the irrigation drip line, while between-row measurements were taken between lines. nonirrigated treatments because fertilizer delivery required water in fertilizer-only plots, necessitating equivalent application to maintain control in nonfertilized, nonirrigated plots. In this sandy soil, moisture applied through drip irrigation does not wet soil between rows. Because irrigation applications are calculated on a land-area basis, it is likely that a significant portion of that irrigation water applied with drip lines percolates through the soil under saturated conditions and is not available for transpiration. Subsequent root development may improve distribution of soil moisture between rows on irrigated sites, but it is likely that predominant root development will occur under drip lines.

\section{Mortality}

A variety of management and pest-related factors caused the wide range of mortality among species. There was no mortality for sycamore or sweetgum; in contrast, total cottonwood mortality was nearly 26 percent (table 5 ) 22.1 percent for ST66 and 29.5 percent for S7C15. Poor stock accounted for 9.6 percent of ST66 mortality and 23.1 percent of S7C15 mortality. Nonrooting occurred in 5.7 percent of ST66 cuttings and 2.7 percent of S7C15 cuttings. Herbicide damage killed 6.8 percent of ST66 cuttings and 3.7 percent of S7C15 cuttings.

Total mortality on loblolly pine was 7.4 percent (table 5). Stock quality and planting accounted for 2.9 percent of the total loblolly pine mortality. A total of 204 trees had pine weevil girdling damage, and 4.5 percent of these were dead (table 5). The high pine weevil incidence was attributed to slash remaining on the site following the recent harvest (Nord and others 1982).

Table 5-Mortality during the $\mathbf{2 0 0 0}$ growing season

\begin{tabular}{|c|c|c|c|c|c|}
\hline \multirow[b]{3}{*}{ Causal agent } & \multicolumn{5}{|c|}{ Tree species or clone ${ }^{a}$} \\
\hline & \multicolumn{2}{|c|}{ Cottonwood } & \multirow[b]{2}{*}{ Sycamore } & \multirow[b]{2}{*}{ Sweetgum } & \multirow{2}{*}{$\begin{array}{l}\text { Loblolly } \\
\text { pine }\end{array}$} \\
\hline & ST66 & S7C15 & & & \\
\hline Stock/establishment & 99 & 237 & 0 & 0 & 30 \\
\hline Herbicide & 70 & 38 & NA & NA & NA \\
\hline Nonrooters & 58 & 28 & NA & NA & NA \\
\hline Weevil damage & NA & NA & NA & NA & 46 \\
\hline Total & 227 & 303 & 0 & 0 & 76 \\
\hline
\end{tabular}

$\mathrm{NA}=$ No mortality was attributed to specified agent.

${ }^{a}$ A total of 1,027 trees were observed for each species. 


\section{Plantation Growth Monitoring}

Root-collar diameter (fig. 8) and height (fig. 9) measurements show consistent fertilizer and irrigation treatment responses. All species showed highly significant fertilizer effects for both diameter and height, and although irrigation effects differed among species, height and diameter responses were consistent within species.

Cottonwood ST66 exhibited positive growth response to both irrigation and fertilization (figs. 8 and 9). In contrast, cottonwood S7C15 did not respond to irrigation at this stage of stand development. The response to irrigation for these two clones is consistent with climatic factors to which they are adapted. Cottonwood ST66 may have high water demand because it originated from along the
Mississippi River Delta where the growing season environment includes high humidity and mesic soil moisture. Clone S7C15 may be more tolerant of low soil moisture because it originated from east Texas where the climate is considerably drier.

The early response of these clones may represent a difference in water use efficiency. Poplar (Populus spp.) genotypes have previously been distinguished on their water use efficiency, stomatal control, and drought tolerance (Ceulemans and others 1978; Gebre and Kuhns 1991; Pallardy and Kozlowski 1979; Schulte and others 1987; Tschaplinski and others 1994, 1998). This experiment demonstrates that those physiological responses result in important growth impacts. Greater tolerance for the dry conditions at Savannah River may be

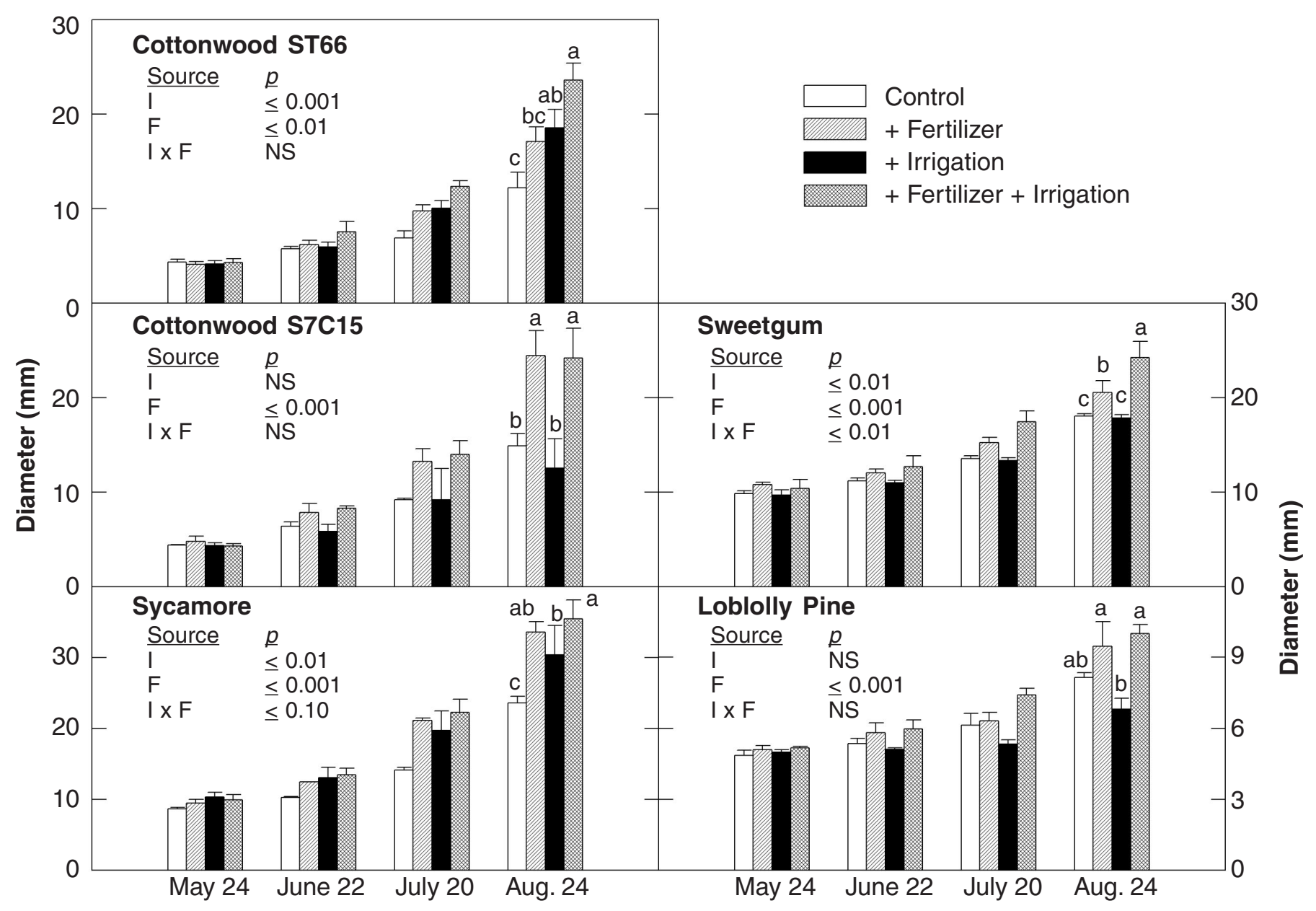

Figure 8-Root-collar diameter growth of the five tree genotypes (cottonwood ST66, cottonwood S7C15, sycamore, sweetgum, and loblolly pine) in response to varying resource availability. Significance levels for irrigation (I) and fertilizer (F) main effects and their interaction (IxF) are shown. Treatments within genotypes not sharing the same letter are significantly different [Tukey's Studentized Range (HSD), $\alpha=0.05$ ]. 


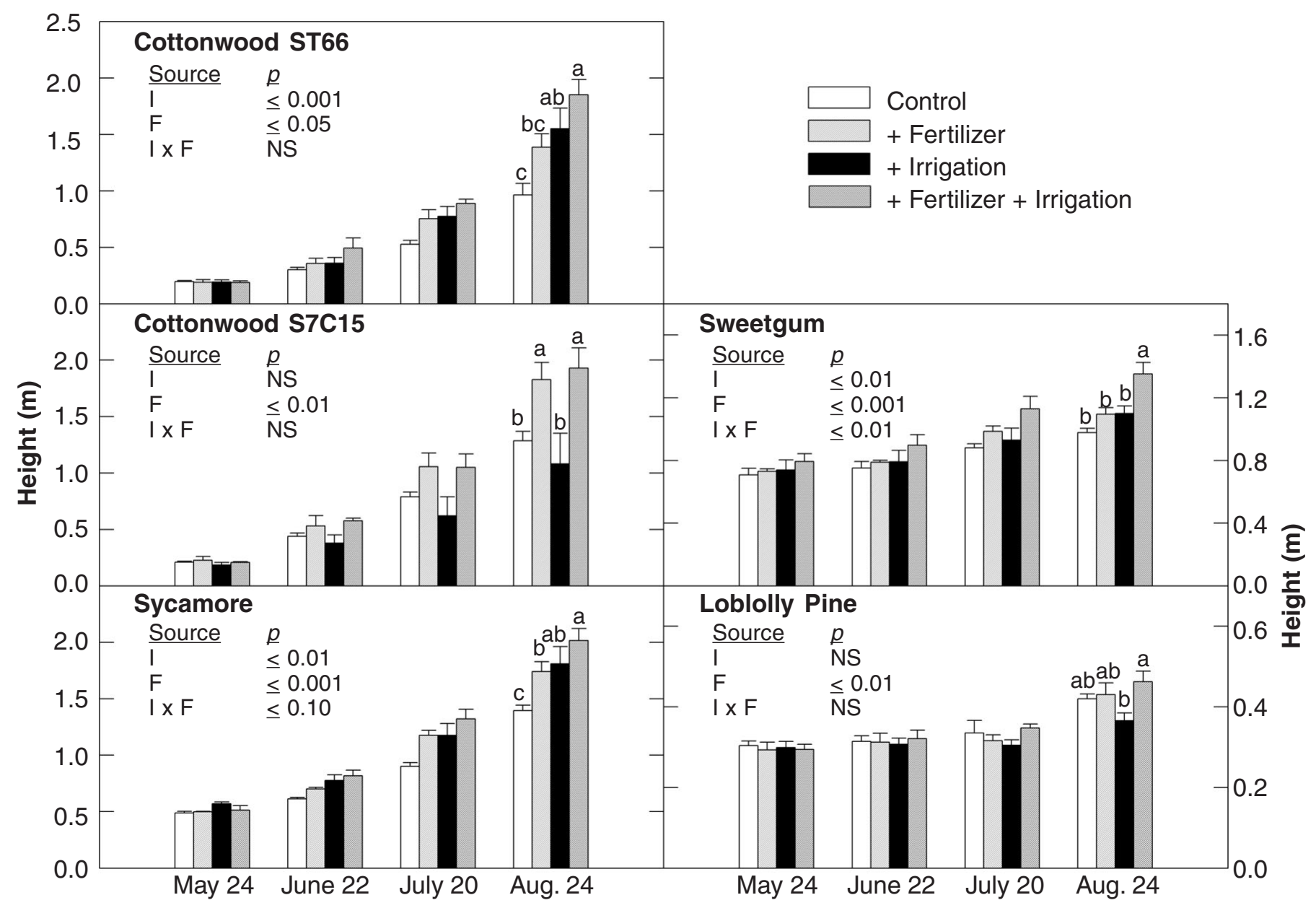

Figure 9-Height growth of the five tree genotypes (cottonwood ST66, cottonwood S7C15, sycamore, sweetgum, and loblolly pine) in response to varying resource availability. Significance levels for irrigation (I) and fertilizer (F) main effects and their interaction (IxF) are shown. Treatments within genotypes not sharing the same letter are significantly different [Tukey's Studentized Range (HSD), $\alpha=0.05$ ].

an important reason clone $\mathrm{S} 7 \mathrm{C} 15$ had larger diameters. Although we do not expect the low demand for irrigation water by S7C15 to continue as the stands develop and occupy the site, we do expect continued water use efficiency differences resulting in superior growth, especially under nonirrigated conditions.

The only other species that did not respond to irrigation was loblolly pine (figs. 8 and 9). A similar lack of irrigation response occurred in other studies where loblolly pine was irrigated (Albaugh and others 1998). Exceptional growth for loblolly pine also occurs when management practices include only competition control and fertilization (Borders and Bailey 2001, Jokela and Martin 2000), suggesting that irrigation is not the limiting factor in the Southeastern United States. Optimal growth of loblolly pine in this region may not require supplemental water because of high water use efficiency. However, there are cases where supplemental irrigation does provide benefits (Samuelson and others 2001). As pine stands fully occupy plots in this study, water requirement will increase. Unless taproots locate a subterranean water source, a significant irrigation effect may develop. The B horizon acts as a confining layer where subsurface flow occurs at this site (Dosskey and Bertsch 1994). At a depth of 120 to $200 \mathrm{~cm}$, this water source may be available to loblolly pine.

The growth response of sycamore and sweetgum to irrigation differed between fertilizer treatments; i.e. the ANOVA shows a significant fertilizer-by-treatment interaction (figs. 8 and 9). Both responded more to 
fertilization than to irrigation, especially for diameter, but the response of sycamore to combined irrigation and fertilization was small compared with that of sweetgum, suggesting that these two species may require different combinations of water and nutrients. As the stands develop, monitoring differences in resource demand will be critical to defining the utility of these woody crops under various growing conditions.

Supplying optimal nutrient requirements is important for maximizing the return on fertilizer applications. We determined optimal requirements by identifying maximum growth responses to various fertilizer levels applied in the regression plots. Again, the response of diameter (fig. 10) and height (fig. 11) growth was similar for each species. Maximum growth response occurred at moderate fertilizer levels for each species except cottonwood S7C15, suggesting that the rates of fertilization will provide valuable information on optimum nutrient requirements among these species. We anticipate the optimum to shift with stand development and as fertilizer treatments are increased to target levels during establishment years.

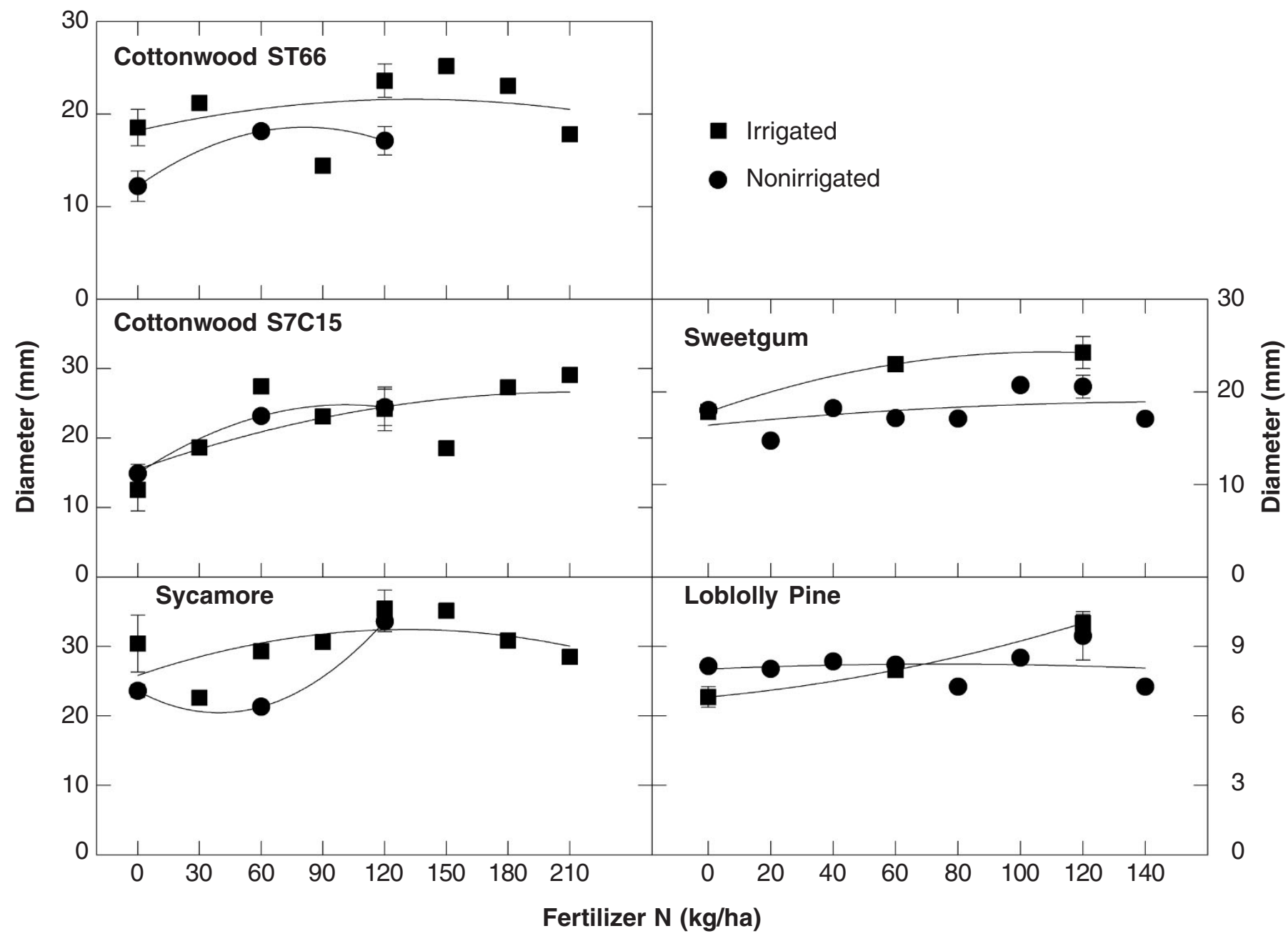

Figure 10-Root-collar diameter for the five tree genotypes (cottonwood ST66, cottonwood S7C15, sycamore, sweetgum, and loblolly pine) grown with or without irrigation across a range of fertilization. Measurements were collected on August 24, 2000. Error bars (SE, $n=3)$ are for replicated analysis-of-variance plots. Points without error bars are for nonreplicated regression plots. Plotted lines are least squares, second-order polynomial regressions. 


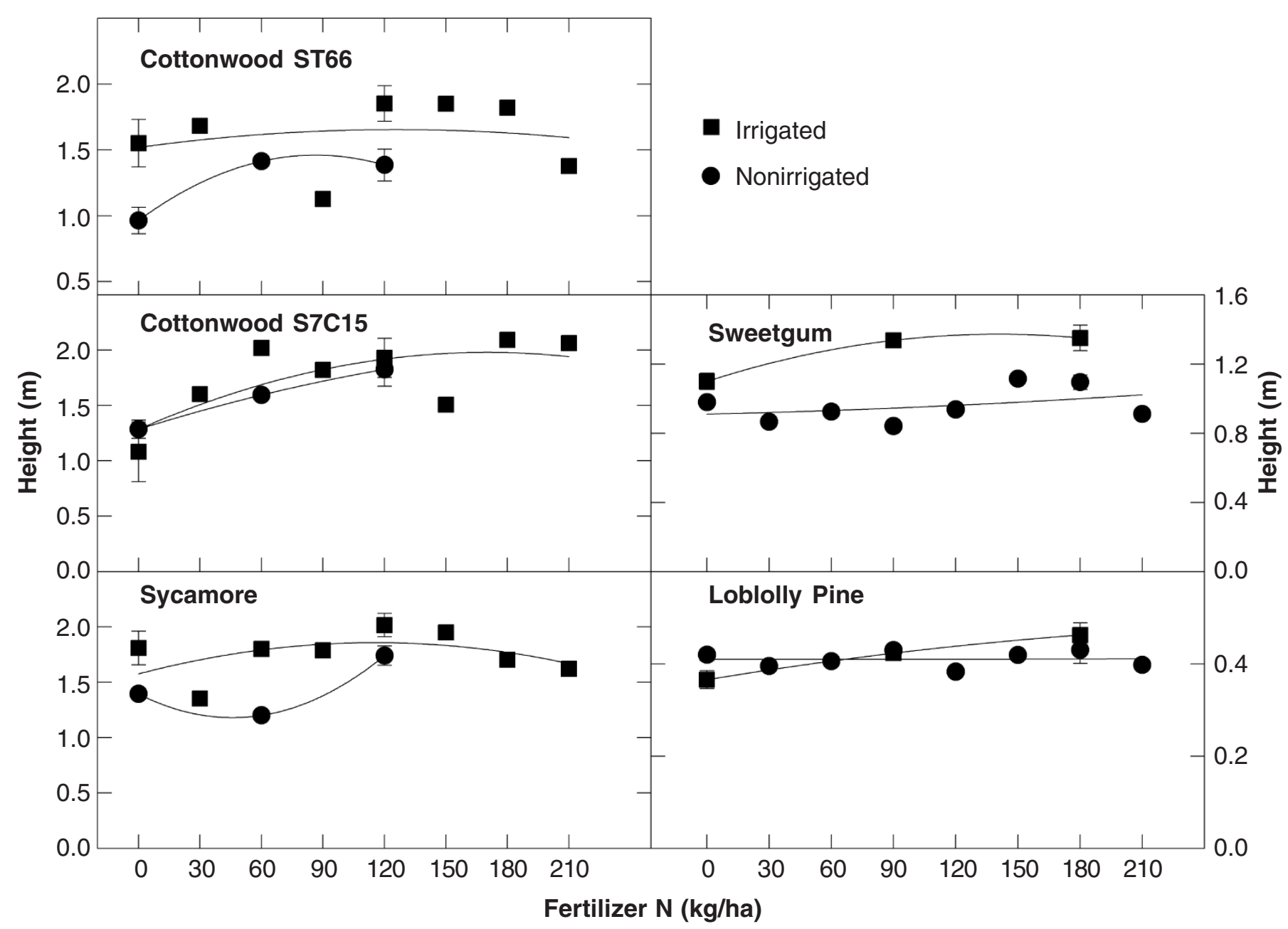

Figure 11-Height for the five tree genotypes (cottonwood ST66, cottonwood S7C15, sycamore, sweetgum, and loblolly pine) grown with or without irrigation across a range of fertilization. Measurements were collected on August 24, 2000. Error bars (SE, $n=3$ ) are for replicated analysis-ofvariance plots. Points without error bars are for nonreplicated regression plots. Plotted lines are least squares, second-order polynomial regressions.

\section{Minirhizotron - Root Growth}

Fine-root density, or live-root standing crop, varied with depth in the soil profile and between species. Fine-root length was greatest at the surface $(0$ to $15 \mathrm{~cm})$ and least at 45 - to $105-\mathrm{cm}$ depth (fig. 12A). Jackson and others (1996) observed similar responses in a wide range of ecosystems. Cottonwood ST66 produced measurable root length at the lowest depth increment but loblolly pine did not. Greater cottonwood root length at lower depths is likely a reflection of different tree sizes between species (figs. 8 and 9).

Cottonwood ST66 produced significantly more roots than loblolly pine in each treatment $(P=0.014)$, with greatest differences at lower depths (fig. 12B). Similarly, in other studies pine and poplar appeared to have such differences in root growth (Coleman and others 2000, Steele and others 1997). Species differences were greatest with nutrient amendments. Cottonwood had more than twice the root length density of loblolly pine with fertilizer additions, but on average, had only 27 percent more root length without nutrient additions. For both species, root length declined with nutrient-only or water-only additions, but root growth increased with combined nutrient and water additions. This interaction between irrigation and fertilization $(P=0.082$ for cottonwood, $P=0.115$ for pine) masked the treatments' main effects $(P>0.8)$. Lower growth in the single-resource treatments may reflect a decrease in the relative proportion of root-to-shoot production compared to controls, despite larger overall tree growth. Both irrigation and fertilization decrease root production or standing crop relative to unamended 

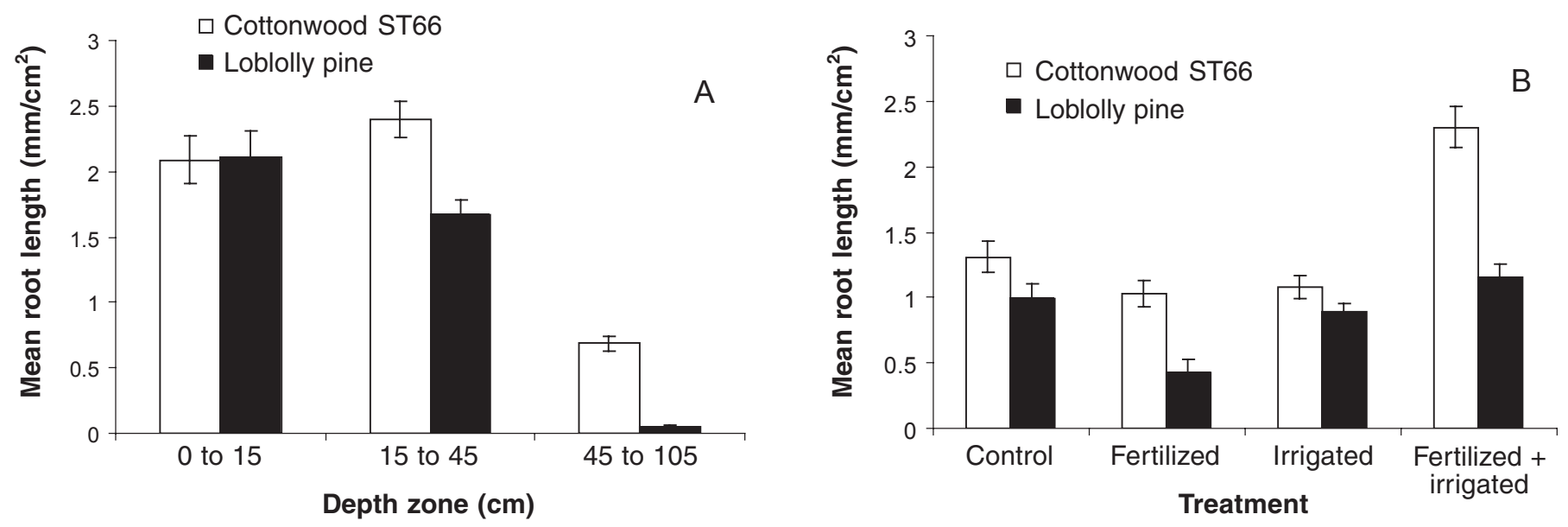

Figure 12-Mean $( \pm$ SE) root length of cottonwood ST66 and loblolly pine per unit minirhizotron surface: $(A)$ at three depth zones with all treatments combined, and (B) in response to fertilizer and irrigation treatments with all depths combined.

treatments (Gower and others 1992, Joslin and Wolfe 1998, Keyes and Grier 1981). Perhaps relative declines in root-toshoot production due to single-resource additions caused an absolute decrease in fine-root density. However, for the plots receiving both irrigation and fertilization, the absolute growth was large enough to overcome the relative root-growth decline caused by available resources. Evaluating changes in root production and turnover will help to assess the processes controlling fine-root density under the conditions of this experiment. Quantifying the dynamics of fine-root production is critical for evaluating the surface area available for acquisition of water and nutrient resources, and the allocation of resources for continued acquisition.

\section{Foliar Nitrogen}

Foliar nitrogen concentrations were seldom different among treatments (table 6). Cottonwood ST66 and sweetgum showed a significant, but small, fertilizer effect.

Table 6-Foliar nitrogen concentrations for hardwoods (sampled in July) and loblolly pine (sampled in December)

\begin{tabular}{|c|c|c|c|c|c|c|}
\hline \multirow[b]{3}{*}{ Treatment } & \multirow[b]{3}{*}{ Source } & \multicolumn{5}{|c|}{ Tree species or clone } \\
\hline & & \multicolumn{2}{|c|}{ Cottonwood } & \multirow[b]{2}{*}{ Sycamore } & \multirow[b]{2}{*}{ Sweetgum } & \multirow[b]{2}{*}{ Loblolly pine } \\
\hline & & ST66 & S7C15 & & & \\
\hline Control & & $2.76 \pm 0.16 \mathrm{ab}$ & $3.25 \pm 0.12 \mathrm{a}$ & $2.43 \pm 0.08 \mathrm{a}$ & $1.90 \pm 0.09 \mathrm{a}$ & $1.64 \pm 0.06 \mathrm{a}$ \\
\hline Fertilized & & $3.06 \pm 0.04 \mathrm{ab}$ & $3.33 \pm 0.12 \mathrm{a}$ & $2.45 \pm 0.06 \mathrm{a}$ & $2.18 \pm 0.09 \mathrm{a}$ & $1.60 \pm 0.07 \mathrm{a}$ \\
\hline Irrigated & & $2.61 \pm 0.12 b$ & $3.33 \pm 0.06 \mathrm{a}$ & $2.23 \pm 0.17 \mathrm{a}$ & $1.95 \pm 0.10 \mathrm{a}$ & $1.70 \pm 0.05 \mathrm{a}$ \\
\hline \multicolumn{7}{|l|}{ Fertilization } \\
\hline + irrigation & & $3.07 \pm 0.10 \mathrm{a}$ & $3.33 \pm 0.10 \mathrm{a}$ & $2.43 \pm 0.18 \mathrm{a}$ & $2.11 \pm 0.02 \mathrm{a}$ & $1.75 \pm 0.08 \mathrm{a}$ \\
\hline & I & NS & NS & NS & NS & NS \\
\hline & $\mathrm{F}$ & $P<0.05$ & NS & NS & $P<0.05$ & NS \\
\hline & FxI & NS & NS & NS & NS & NS \\
\hline
\end{tabular}

$\mathrm{I}=$ Irrigation; F = fertilization; FxI = interaction; NS = not significant.

Mean \pm sem, $\mathrm{n}=12$.

Significant analysis-of-variance probabilities are included for irrigation, fertilization, and the interaction.

Means followed by the same letter in each column are not significantly different [Tukey's Studentized Range (HSD), $\alpha=0.1$ ]. 
Orthogonal contrast mean separations helped identify differences in sweetgum. Cottonwood clones had greater N concentration than other species, whereas loblolly pine and sweetgum had the lowest concentrations. Other nutrients also showed similar small differences among treatments (data not shown). Subtle differences in nutrient concentrations among treatments indicate that tree growth is limited by available nutrients. Increased nutrient availability clearly stimulated growth (figs. $8,9,10$, and 11 ), yet there is no accumulation of foliar nutrient concentrations. Therefore, it appears that the trees are growing to the limits of available nutrients, exhibiting dilution of acquired nutrients through proportionally increased biomass.

\section{Leaf Area}

Leaf area development during the growing season was closely related to stem diameter growth (fig. 13). Power functions best fit the data $\left(R^{2}>0.9\right)$, which is typical for this type of allometric relationship (Jokela and Martin 2000, Landsberg and Gower 1997). Parameters from these functions predicted LAI from plot diameter measurements (fig. 14). LAI for this young plantation is still small, but distinct species differences are evident. Sycamore has the greatest development followed by cottonwood S7C15, ST66; sweetgum; and loblolly pine. The relationship among species is likely to change as canopies develop.
Addition of water and nutrients frequently resulted in greater leaf area development compared with the controls. These differences were not always statistically significant (fig. 14). Fertilization generally increased LAI, but irrigation did not always increase it. Greatest LAI occurred in the combined treatment for each species except cottonwood S7C15, where the nutrient-only treatment was greatest. As with other studies (Cannell and others 1988, Jokela and Martin 2000, Landsberg and others 1997), leaf area development in our study closely parallels growth. Therefore, we may estimate stand vigor and productivity response to nutrient additions through canopy analysis, but need data throughout stand development to factor out age and ontogenetic effects.

\section{Conclusions}

In this study, each of the species responded to fertilization, and less distinct responses occurred with irrigation. At this early stage of stand development, tree genotypes with greater relative drought tolerance responded much less to irrigation than water-loving varieties. Treatment responses are generally consistent among collected measurements, including stem diameter, height, root density, and leaf area development. The two main processes of nutrient acquisition and leaf area development control growth. To understand more fully the controls of growth and

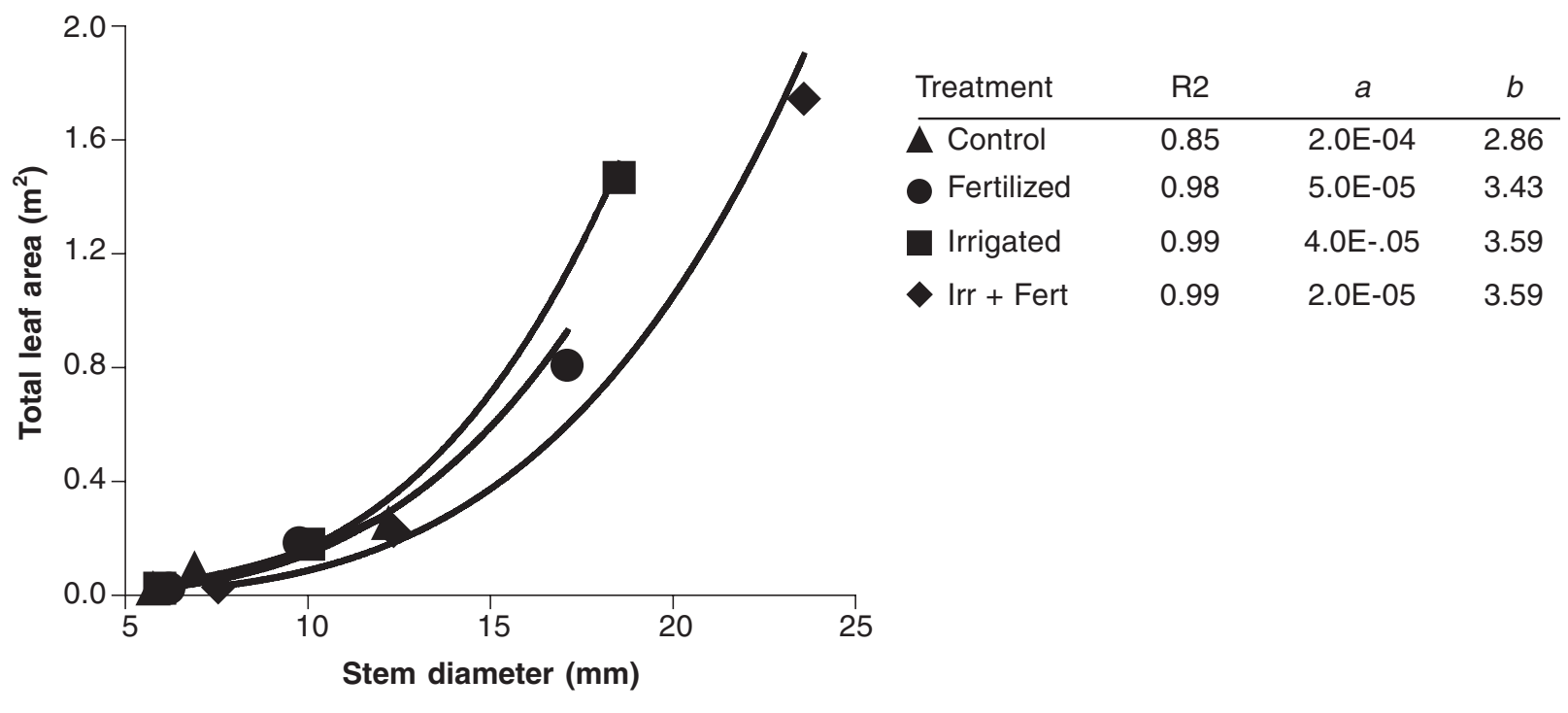

Figure 13-Example of allometric leaf area relationships for cottonwood ST66. Whole-tree leaf area is related to stem diameter (D) by a power function: LA $=a \mathrm{D}^{b}$, where $a$ and $b$ are least-squares regression coefficients. 

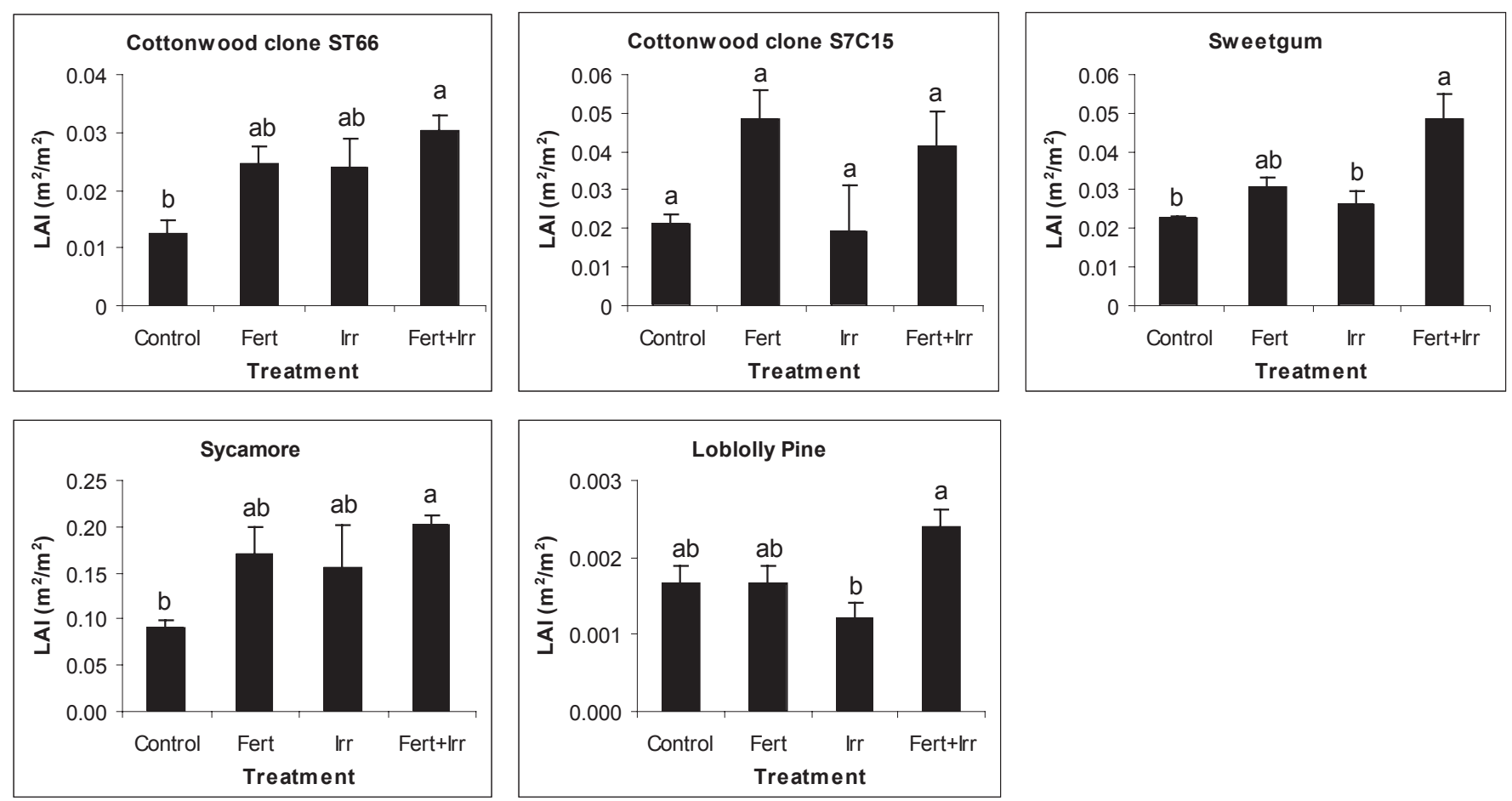

Figure 14-Leaf area index (LAI) measurements for the five tree genotypes (cottonwood ST66, cottonwood S7C15, sycamore, sweetgum, and loblolly pine) in July 2000. Means sharing a letter are not significantly different [Tukey's Studentized Range (HSD), $\alpha=0.05$ ].

productivity under varying resource availability, we need information on uptake surface and the activity of that surface for resource acquisition. This experimental facility has established a variety of tree species growing with a range of resource availability treatments. Continued monitoring will examine the processes controlling growth of forest plantations. This critical information will be valuable for understanding biological processes controlling forest growth, as well as management of forest stands for forest products, bioenergy feedstock production, carbon and nitrogen sequestration, and phytoremediation potential.

\section{Acknowledgments}

Funding for this project came from the U.S. Department of Energy, Savannah River Operations Office through the U.S. Department of Agriculture Forest Service, Savannah River, under Interagency Agreement DE-IA0900SR22188; and from sponsors of the Short-Rotation
Woody Crops Cooperative Research Program including Weyerhaeuser, The Timber Company, Union Camp, Champion International, Bioenergy Feedstock Development Program, Oak Ridge National Laboratory, and U.S. Department of Agriculture Forest Service, Southern Research Station Research Work Units SRS4103, SRS-4104, SRS-4154, SRS-4505, and SRS-4703. Many Savannah River site personnel working for subcontracting agencies including the U.S. Department of Agriculture Forest Service, Savannah River and Southern Research Station; Savannah River Technology Center; and Savannah River Ecology Laboratory. Specific individuals have been invaluable in assisting with this project, including Dave Wilson, Ron Bonar, Homer Gabard, Cindy Possee, Bob Morgan, Ron Mosley, Jamie Scott, Dan Strawbridge, Don Coulter, Kevin Korman, and Sandy Wilkins. Individuals from other organizations that helped in planning and initiating this project include Neil Dulohery, Hank Page, Dan Robison, Dennis DeFrancesco, Marianne Burke, Diane DeStevens, Chris Barton, and Julian Singer. 


\section{Literature Cited}

Anon. 1997. A model for soil nutrient uptake and harvest removals in loblolly pine plantations. Raleigh, NC: North Carolina State University. 24 p.

Albaugh, T.J.; Allen, H.L.; Dougherty, P.M. [and others]. 1998. Leaf area and above- and belowground growth responses of loblolly pine to nutrient and water additions. Forest Science. 44: 317-328.

Allen, H.L.; Dougherty, P.M.; Campbell, R.G. 1990. Manipulation of water and nutrients - practice and opportunity in Southern U.S. pine forests. Forest Ecology and Management. 30: 437-453.

Anderson, V.; McLean, R. 1974. Design of experiments, a realistic approach. New York: Marcel Dekker. 418 p.

Borders, B.E.; Bailey, R.L. 2001. Loblolly pine - pushing the limits of growth. Southern Journal of Applied Forestry. 25: 69-74.

Box, G.; Draper, N. 1987. Empirical model-building and response surfaces. New York: John Wiley. 669 p.

Cannell, M.G.R. 1989. Physiological basis of wood production: a review. Scandinavian Journal of Forest Research. 4: 459-490.

Cannell, M.G.R.; Dewar, R.C. 1994. Carbon allocation in trees: a review of concepts for modelling. Advances in Ecological Research. 25: 59104

Cannell, M.G.R.; Sheppard, L.J.; Milne, R. 1988. Light use efficiency and woody biomass production of poplar and willow. Forestry. 61: 125136.

Ceulemans, R.; Impens, I.; Lemeur, R. [and others]. 1978. Water movement in the soil-poplar-atmosphere system II. Comparative study of the transpiration regulation during water stress situations in four different poplar clones. Oecologia Plantarum. 13: 139-146.

Ceulemans, R.; Scarascia-Mugnozza, G.; Wiard, B.M. [and others]. 1992 Production physiology and morphology of Populus species and their hybrids grown under short rotation. I. Clonal comparisons of 4-year growth and phenology. Canadian Journal of Forest Research. 22: 12.

Coleman, M.D.; Dickson, R.E.; Isebrands, J.G. 2000. Contrasting fineroot production, survival and soil $\mathrm{CO}_{2}$ efflux in pine and poplar plantations. Plant and Soil. 225: 129-139.

Dickmann, D.I.; Stuart, K.W. 1983. The culture of poplars in Eastern North America. East Lansing, MI: Michigan State University Press. $168 \mathrm{p}$

Dosskey, M.G.; Bertsch, P.M. 1994. Forest sources and pathways of organic matter transport to a blackwater stream: a hydrologic approach. Biogeochemistry. 24: 1-19.

Gebre, G.M.; Kuhns, M.R. 1991. Seasonal and clonal variations in drought tolerance of Populus deltoides. Canadian Journal of Forest Research. 21: 910-916.

Gomez, K.; Gomez, A. 1984. Statistical procedures for agricultural research. New York: John Wiley. 680 p.
Gower, S.T.; Vogt, K.A.; Grier, C.C. 1992. Carbon dynamics of Rocky Mountain Douglas-fir: influence of water and nutrient availability. Ecological Monographs. 62: 43-65.

Heilman, P.E.; Stettler, R.F. 1986. Nutritional concerns in selection of black cottonwood and hybrid clones for short rotation. Canadian Journal of Forest Research. 16: 860-863.

Jackson, R.B.; Canadel, J.; Ehleringer, J.R. [and others]. 1996. A global analysis of root distributions for terrestrial biomes. Oecologia. 108: 389-411.

Johnson, D.W. 1992. Nitrogen retention in forest soils. Journal of Environmental Quality. 21: 1-21

Jokela, E.J.; Martin, T.A. 2000. Effects of ontogeny and soil nutrient supply on production, allocation, and leaf area efficiency in loblolly and slash pine stands. Canadian Journal of Forest Research. 30: 15111524.

Joslin, J.D.; Wolfe, M.H. 1998. Impacts of water input manipulations on fine root production and mortality in a mature hardwood forest. Plant and Soil. 204: 165, 174.

Keyes, M.R.; Grier, C.C. 1981. Above- and below-ground net production in 40-year-old Douglas-fir stands on low and high productivity sites. Canadian Journal of Forest Research. 11: 599-605.

Kleinbaum, D.G.; Kupper, L.L. 1978. Applied regression analysis and other multivariable methods. Boston: Duxbury Press. 556 p.

Landsberg, J.J.; Gower, S.T. 1997. Applications of physiological ecology to forest management. New York: Academic Press. 354 p.

Landsberg, J.J.; Prince, S.D.; Jarvis, P.G. [and others]. 1997. Energy conversion and use in forests: an analysis of forest production in terms of radiation utilisation efficiency. In: Gholz, H.L.; Nakane, K.; Shimoda, H., eds. The use of remote sensing in the modeling of forest productivity at scales from the stand to the globe. Dordrecht: KluwerAcademic Publishers: 273-298.

Linder, S.; Benson, M.L.; Myers, B.J.; Raison, R.J. 1987. Canopy dynamics and growth of Pinus radiata. I. Effects of irrigation and fertilization during a drought. Canadian Journal of Forest Research. 10: $1157-1165$

Nelson, L.E.; Switzer, G.L.; Lockaby, B.G. 1987. Nutrition of Populus deltoides plantations during maximum production. Forest Ecology and Management. 20: 25-41.

Nord, J.C.; Ghent, J.H.; Thomas, H.A.; Doggett, C.A. 1982. Control of pales and pitch-eating weevils in the South. For. Rep. SA-FR 21. Atlanta: U.S. Department of Agriculture, Forest Service, Southern Region. 24 p.

Pallardy, S.G.; Kozlowski, T.T. 1979. Relationships of leaf diffusion resistance of Populus clones to leaf water potential and environment. Oecologia. 40: 371-380.

Pastor, J.; Aber, J.D.; McClaugherty, C.A.; Melillo, J.M. 1984. Aboveground production and $\mathrm{N}$ and $\mathrm{P}$ cycling along a nitrogen mineralization gradient on Blackhawk Island. Ecology. 65: 256-268. 
Reich, P.B.; Grigal, D.F.; Aber, J.D.; Gower, S.T. 1997. Nitrogen mineralization and productivity in 50 hardwood and conifer stands on diverse soils. Ecology. 78: 335-347.

Samuelson, L.; Stokes, T.; Cooksey, T.; McLemore, P. 2001. Production efficiency of loblolly pine and sweetgum in response to four years of intensive management. Tree Physiology. 21: 369-376.

Saxton, K.E.; Rawls, W.J.; Romberger, J.S.; Papendick, R.I. 1986 Estimating generalized soil-water characteristics from texture. Soil Science Society of America Journal. 50: 1031-1036.

Schulte, P.J.; Hinckley, T.M.; Stettler, R.F. 1987. Stomatal responses of Populus to leaf water potential. Canadian Journal of Botany. 65: 255260.

Sims, J.T. 1996. Lime requirement. Methods of soil analysis. Part 3. Chemical methods. Madison, WI: Soil Science Society of America: 491-515.

Stanturf, J.A.; van Oosten, C.; Netzer, D.A. [and others]. 2001. Ecology and silviculture of poplar plantations. In: Dickmann, D.I.; Isebrands, J.G.; Eckenwalder, J.E.; Richardson, J., eds. Poplar culture in North America. Ottawa, Canada: National Research Council: 153-206.

Steele, S.J.; Gower, S.T.; Vogel, J.G.; Norman, J.M. 1997. Root mass, net primary production and turnover in aspen, jack pine and black spruce forests in Saskatchewan and Manitoba, Canada. Tree Physiology. 17: 577-587.

Steinbeck, K.; Skinner, T.M. 1985. Growing short-rotation forests in the Southeastern USA. In: Egneus, H.; Ellegard, A., eds. Biomass resources. Elsevier: 63-69.
Tschaplinski, T.J.; Tuskan, G.A.; Gebre, G.M.; Todd, D.E. 1998 Drought resistance of two hybrid Populus clones grown under irrigation in large-scale plantations. Tree Physiology. 18: 645652 .

Tschaplinski, T.J.; Tuskan, G.A.; Gunderson, C.A. 1994. Water stress tolerance of black cottonwood and eastern cottonwood clones and four of their hybrid progeny. I. Growth, water relations and gas exchange. Canadian Journal of Forest Research. 24: $364-371$.

Tuskan, G.A. 1998. Short-rotation woody crop supply systems in the United States: what do we know and what do we need to know? Biomass and Bioenergy. 14: 307-315.

U.S. Department of Commerce, National Oceanographic and Atmospheric Administration. 1993. Climatological data annual summary: South Carolina. Asheville, NC. 26 p. Vol. 96.

U.S. Department of Commerce, National Oceanographic and Atmospheric Administration. 1997. Climatological data annual summary: South Carolina. Asheville, NC. 19 p. Vol. 100.

Van Bavel, C.H.M. 1966. Potential evaporation: the combination concept and its experimental verification. Water Resources Research. 2: 19-31.

Vogt, K. 1991. Carbon budgets of temperate forest ecosystems. Tree Physiology. 9: 69-86.

Vose, J.A.; Allen, H.L. 1988. Leaf area, stemwood growth, and nutrition relationships in loblolly pine. Forest Science. 34: 547-563.

Yin, R.; Sedjo, R.A. 2001. Is this the age of intensive management? A study of loblolly pine in Georgia's Piedmont. Journal of Forestry. 99: $10-17$. 

Coleman, M.D.; Coyle, D.R.; Blake, J.; Britton, K.; Buford, M.; Campbell, R.G.; Cox, J.; Cregg, B.; Daniels, D.; Jacobson, M.; Johnsen, K.; McDonald, T.; McLeod, K.; Nelson, E.; Robison, D.; Rummer, R.; Sanchez, F.; Stanturf, J.; Stokes, B.; Trettin, C.; Tuskan, J.; Wright, L.; Wullschleger, S. 2004. Production of short-rotation woody crops grown with a range of nutrient and water availability: establishment report and first-year responses. Gen. Tech. Rep. SRS-72. Asheville, NC: U.S. Department of Agriculture, Forest Service, Southern Research Station. 21 p.

Many researchers have studied the productivity potential of intensively managed forest plantations. However, we need to learn more about the effects of fundamental growth processes on forest productivity; especially the influence of above- and belowground resource acquisition and allocation. This report presents installation, establishment, and first-year results of four tree species (two cottonwood clones, sycamore, sweetgum, and loblolly pine) grown with fertilizer and irrigation treatments. At this early stage of development, irrigation and fertilization were additive only in cottonwood clone ST66 and sweetgum. Leaf area development was directly related to stem growth, but root production was not always consistent with shoot responses, suggesting that allocation of resources varies among treatments. We will evaluate the consequences of these early responses on resource availability in subsequent growing seasons. This information will be used to: (1) optimize fiber and bioenergy production; (2) understand carbon sequestration; and (3) develop innovative applications such as phytoremediation; municipal, industrial, and agricultural wastes management; and protection of soil, air, and water resources.

Keywords: Allocation, fertigation, fine-root growth, intensive management, interspecific comparisons, leaf area. 

Agriculture (USDA), is dedicated to the principle of multiple use management of the Nation's forest resources for sustained yields of wood, water, forage, wildlife, and recreation. Through forestry research, cooperation with the States and private forest owners, and management of the National Forests and National Grasslands, it strives - as directed by Congress - to provide increasingly greater service to a growing Nation.

The USDA prohibits discrimination in all its programs and activities on the basis of race, color, national origin, sex, religion, age, disability, political beliefs, sexual orientation, or marital or family status. (Not all prohibited bases apply to all programs.) Persons with disabilities who require alternative means for communication of program information (Braille, large print, audiotape, etc.) should contact USDA's TARGET Center at (202) 720-2600 (voice and TDD).

To file a complaint of discrimination, write USDA, Director, Office of Civil Rights, Room 326-W, Whitten Building, 1400

Independence Avenue, SW, Washington, D.C. 20250-9410 or call (202) 720-5964 (voice and TDD). USDA is an equal opportunity provider and employer. 